\title{
Insecticidal Activity of Bacillus thuringiensis Proteins against Coleopteran Pests
}

\author{
Mikel Domínguez-Arrizabalaga ${ }^{1}$, Maite Villanueva ${ }^{1,2}{ }^{\circledR}$, Baltasar Escriche ${ }^{3} \mathbb{C}^{\text {, }}$ \\ Carmen Ancín-Azpilicueta ${ }^{4}$ and Primitivo Caballero ${ }^{1, *}$ \\ 1 Institute for Multidisciplinary Research in Applied Biology-IMAB, Universidad Pública de Navarra, \\ 31192 Mutilva, Navarra, Spain; mikel.dominguez@unavarra.es (M.D.-A.); \\ maite.villanueva@unavarra.es (M.V.) \\ 2 Bioinsectis SL, Avda Pamplona 123, 31192 Mutilva, Navarra, Spain \\ 3 Departamento de Genética/ERI BioTecMed, Universitat de València, Burjassot, 46100 València, Spain; \\ baltasar.escriche@uv.es \\ 4 Departamento de Ciencias, Universidad Pública de Navarra, 31006 Pamplona, Spain; ancin@unavarra.es \\ * Correspondence: pcm92@unavarra.es; Tel.: +34-948-168-004
}

Received: 4 June 2020; Accepted: 25 June 2020; Published: 29 June 2020

\begin{abstract}
Bacillus thuringiensis is the most successful microbial insecticide agent and its proteins have been studied for many years due to its toxicity against insects mainly belonging to the orders Lepidoptera, Diptera and Coleoptera, which are pests of agro-forestry and medical-veterinary interest. However, studies on the interactions between this bacterium and the insect species classified in the order Coleoptera are more limited when compared to other insect orders. To date, 45 Cry proteins, 2 Cyt proteins, 11 Vip proteins, and 2 Sip proteins have been reported with activity against coleopteran species. A number of these proteins have been successfully used in some insecticidal formulations and in the construction of transgenic crops to provide protection against main beetle pests. In this review, we provide an update on the activity of Bt toxins against coleopteran insects, as well as specific information about the structure and mode of action of coleopteran Bt proteins.
\end{abstract}

Keywords: Bacillus thuringiensis proteins; coleopteran pests; insecticidal activity; structure; mode of action

Key Contribution: This contribution provide an update on the activity of Bt toxins against coleopteran insects.

\section{Introduction}

The use of entomopathogenic microorganisms as biological control agents has become one of the most effective alternatives to chemical pest control. Among all, the Gram-positive bacterium Bacillus thuringiensis $(\mathrm{Bt})$ is the most important entomopathogenic microorganism used to date in crop protection. This bacterium is widely distributed in various ecological niches, such as water, soil, insects, and plants [1]. The feature that distinguishes B. thuringiensis from other members of the Bacillus group is the capacity to produce parasporal crystalline inclusions. These crystals are composed of proteins (Cry and Cyt) which are toxic against an increasing number of insect species from the orders Lepidoptera, Diptera, Coleoptera, Hymenoptera, and Hemiptera, among others, as well as against other organisms such as mites [2] and nematodes [3]. Bt also synthesizes insecticidal toxins associated with the vegetative growth phase, named Vip (vegetative insecticidal protein) and Sip (secreted insecticidal protein), which are secreted into the growth medium [4]. These toxins are uniquely specific, safe, and completely biodegradable, and have been used for more than 60 years as an alternative to 
chemical insecticides [5]. Products based on Bt isolates are the most successful microbial insecticides, with current worldwide benefits estimated at $\$ 8$ billion annually [6]. However, not all Bt proteins are designated as toxins, for example, some parasporins do not have known insect targets, although they are toxic to human cancer cells [7]. The insecticidal activity of Bt toxins has also been transferred to crop plants through genetic engineering, providing very high protection levels against injurious pests and decreasing the use of chemical insecticides in many instances [8,9]. The success of these insecticidal proteins has fuelled the search for new Bt isolates and proteins that can render novel insecticidal agents with different specificities.

Since Schnepf and Whiteley cloned the first cry gene in the early 1980's [10], many others have been described and are now classified according to Bt Toxin Nomenclature, that consists of four ranks based on amino acid sequence identity [11]. To date, the Bt Toxin Nomenclature Committee [12] has reported at least 78 Cry protein groups, from Cry1 to Cry 78, divided into at least three phylogenetically non-related protein subfamilies that may have different modes of action: the three-domain Cry toxins (3-domain), the mosquitocidal Cry toxins (Etx_Mtx2), Toxin_10 proteins, and alpha-helical toxins (reviewed in $[13,14])$.

The largest group, with more than 53 Cry toxin subgroups, is the 3-domain Cry toxin group. Even though the sequence identity among these proteins is low, the overall structure of the three domains is quite similar, providing proteins with different specificities but with quite similar modes of action [15]. Thus, proteins such as Cry1Aa (lepidopteran specific) and Cry3Aa (coleopteran specific) have a $32.5 \%$ identity but a structural similarity as high as $98 \%$ [16]. Phylogenetic analysis shows that the great variability in the insecticidal activity of this 3-domain group has resulted from the independent evolution of the three structural domains as well as from the swapping of domain III between different toxins [15].

Due to their feeding habits, many species of coleoptera cause serious damage to both cultivated plants and stored products, leading to significant economic losses in all regions of the world [17,18]. Both larvae and adults have strong jaws, which enable them to feed on a wide variety of plant substrates, such as roots, stems, leaves, grains or wood [19]. Beetles represent the order of the Insecta class that includes the largest number of species. However, the studies carried out to identify toxins of $B$. thuringiensis active against beetles are far from being equal to those carried out in the order Lepidoptera. Thus, 45 Cry proteins, 2 Cyt proteins, 11 Vip proteins, and 2 Sip proteins have been reported with activity against coleopteran insects to date, of which the toxins of the Cry3 and Cry 8 families have the largest host spectrum (Figure 1). In this review, we provide an update on the activity of $\mathrm{Bt}$ toxins against coleopteran pests.

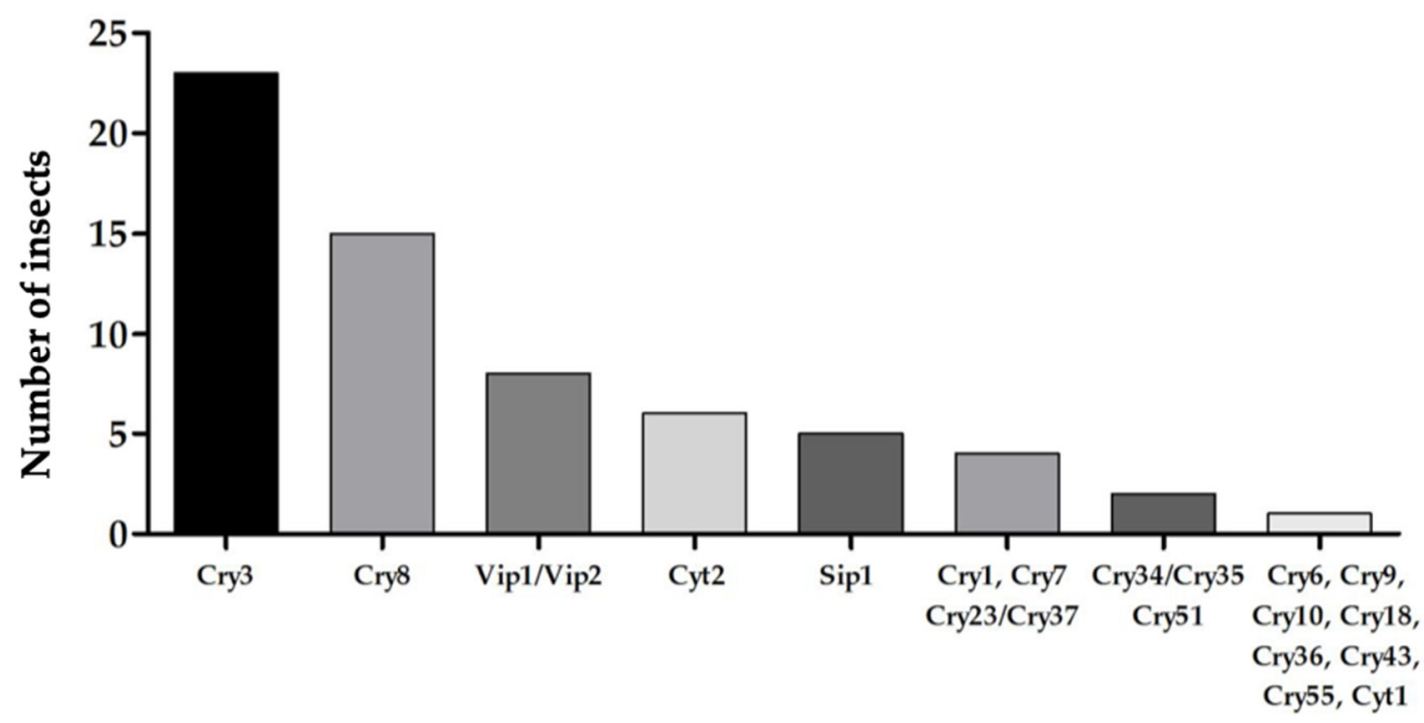

Figure 1. Number of susceptible coleopteran insects to Bt (Bacillus thuringiensis) proteins, grouped into protein families. 


\section{The Crystal Coleopteran-Active Proteins}

$B t$ crystal proteins ( $\delta$-endotoxins) are produced during the stationary growth phase and have been isolated from a wide range of insect pests. These crystal inclusions are mainly formed by Cry and Cyt proteins that are toxic to a wide variety of insect species. Most of the information on the insecticidal properties has been obtained for the Cry3 family, and only a few data come from other Cry families. The Cyt proteins constitute a smaller group, mainly active against dipterans, although some Cyt proteins are toxic to coleopteran pests and increase the potential of certain Cry toxins [20].

\subsection{Protein Structure}

As mentioned above, Bt Cry proteins can be basically subdivided into three different groups according to their homology and molecular structure: the 3-domain group, Etx_Mtx2 proteins, Toxin_10 proteins, and alpha-helical toxins. The 3-domain Cry proteins constitute the largest and best-studied group, although there is increasing information on the 'non-3-domain' and Cyt proteins.

\subsubsection{The 3-Domain Group Toxins}

All 3-domain Cry proteins are produced as protoxins of two main sizes, a $\sim 130 \mathrm{kDa}$ protoxin and shorter one of approximately $70 \mathrm{kDa}$ [16] (Figure 2). The $130 \mathrm{kDa}$ proteins share a highly conserved $\mathrm{C}$ terminus containing 15-17 cysteine residues, which is dispensable for toxicity but necessary for the formation of intermolecular disulphide bonds during crystal formation [15,21]. This group has been mainly studied on lepidopteran toxins such as Cry1A, but also includes some coleopteran active toxins such as Cry7A and Cry8. The structure of the small protoxins is quite similar to the N-terminal half of the large toxin group. Since these do not contain the C-terminal extension, they require, in some cases, the presence of accessory proteins for crystallization [22,23]. This second group includes Cry2A, Cry11A, and some toxins active against Coleoptera, such as Cry3A or Cry3B. Proteolytic cleavage of the $\mathrm{N}$-terminal peptide and the $\mathrm{C}$-terminal extension (mainly in the long Cry protoxins) yields active $\sim 60 \mathrm{kDa}$ protease-resistant fragments [24]. The first crystal structure solved by X-ray crystallography was the coleopteran-specific Cry3Aa [25]. Since then, the tertiary structure of other six 3-domain Cry active proteins, including Cry1Aa, Cry2Aa, Cry3Bb, Cry4Aa, Cry4Aa, Cry4Ba and Cry8Ea, has been determined [26-31]. Among all, Cry3Aa, Cry3Bb and Cry8Ea have been defined as coleopteran-active proteins (Figure 3A,B). Using the FATCAT server [32], the structural alignment between these anti-coleopteran proteins is significantly similar, despite their low sequence identity. Pardo-López et al. [16] analyzed the structural similarity between Cry1Aa and the other 3-domain Cry proteins aforementioned, indicating the same structural likeness. The marked similarity in terms of the structure of the 3-domain Cry proteins, despite the low sequence identity and the differences in specificity, has rendered different proteins with similar modes of action.

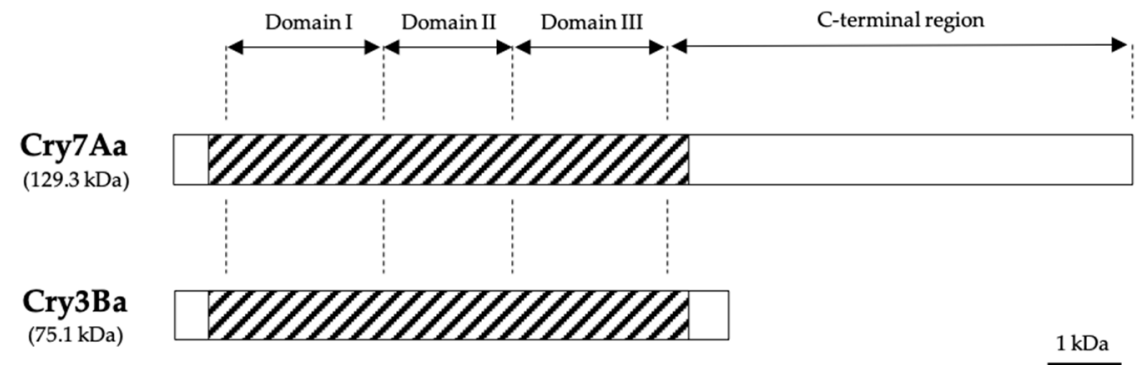

Figure 2. Relative length of 3-domain Cry proteins of B. thuringiensis, representing both main sizes of approximately 130 and $70 \mathrm{kDa}$. Dashed parts represent the activated toxin, while the white boxes represent the amino- and carboxy-terminal parts. Adapted from Bravo et al., 2007 [33].

Domain I consists of six $\alpha$-helix surrounding a hydrophobic helix- $\alpha 5$. This domain, which shares strong similarities with the structure of the pore-forming domain of $\alpha+$ PFTs colicin A, might be 
responsible for membrane penetration and pore formation [23]. The binding domain II is constituted by three antiparallel $\beta$-sheets packing together and has an important role in receptor binding affinity. Finally, domain III is a two-twisted anti-parallel $\beta$-sheet and is also involved in receptor binding and pore formation [24,34]. Although it has been demonstrated that domains I and II have co-evolved over the years, swapping by homologous recombination of domain III has also been reported [15,35]. Local alignment of coleopteran-active Cry3, Cry7, and Cry8 showed that domain I was strongly conserved while domains II and III diversified [35]. Bt might use this mechanism to get adapted to a new insect host, which may explain the great variability in the biocidal activity of the 3-domain Cry proteins.

\subsubsection{Non-3-Domain Cry Toxins}

In addition to the 3-domain Cry proteins, some unrelated Cry proteins are also designated by the Cry nomenclature: Etx_Mtx2 proteins, Toxin_10 proteins and alpha-helical toxins [4]. The structure and function of Etx_Mtx2 proteins remains unclear, although the similarities with the Clostridium perfringens epsilon toxin (closely related to aerolysin) seem to indicate that they may have a $\beta$-sheet-based structure and a pore-forming activity [36]. It is important to notice that, while most of them have activity by themselves, some toxins are proposed as protein complexes to induce mortality, such as the Etx_Mtx2 protein Cry23 and the Cry37 protein [37]. The crystal structure of Cry23Aa reveals a single $\beta$-stranded domain protein, with structural similarity to several $\beta$-pore forming toxins as proaerolysins, produced by other bacterial species [38]. Cry37Aa conforms to a C2 $\beta$-sandwich fold, similar to the calcium phospholipid-binding domain observed in human cytosolic phospholipase A2 (Figure 3C) [38]. Moreover, the toxins Cry34 and Cry35 have been reported to have binary activity against coleopteran insects $[39,40]$. Crystal structures of Cry34Ab and Cry35Ab have been published (Figure 3D). Cry35Ab, a member of Toxin_10 proteins, shows an aerolysin-like fold, containing a $\beta$-trefoil N-terminal domain similar to the carbohydrate-binding domain in Mtx1. Cry34Ab is also a member of the aerolysin family with a $\beta$-sandwich fold, common among other cytolytic proteins [41].

\subsubsection{Cyt Proteins}

Similar to the Cry proteins, Cyt proteins are produced as protoxins with a proteolytically activated size of around $25 \mathrm{kDa}$ [20]. As with some Cry proteins, the tertiary structure of some Cyt proteins has already been solved. Cyt1Aa [42], Cyt2Aa [43] and Cyt2Ba [44] show a similar structure composed of a single $\alpha$ - $\beta$-domain, with two outer layers of $\alpha$-helix wrapped around a $\beta$-sheet (Figure 3E). Studies performed with peptides of Cyt1A show that $\alpha$-helix peptides are major structural elements involved in membrane interaction [45] and also in the oligomerization process [46], while the $\beta$-strand forms an oligomeric pore with a $\beta$-barrel structure into the membrane [43].

\subsection{Insecticidal Activity}

The vast majority of Cry proteins described to date are toxic to lepidopteran pests, but there are also a few crystal proteins toxic to either coleopteran or dipteran insects, and a small number are toxic to nematodes [47]. Currently, 45 Bt crystal proteins, including Cry, Cyt or binary proteins, have been tested against different coleopteran insects (Table 1).

\subsubsection{Host Range}

Cry proteins are toxic to a large number of beetle pests. Mainly, the Cry3 group, the best-studied one, has been described with activity against most of the coleopteran species assayed. These Cry proteins, encoded by cry3 genes, were first discovered in the subspecies tenebrionis [48] and san diego [49] although, years later, both strains turned out to be the same subsp. [50]. Since then, more isolates like Bt subsps. tolworthi, kumamotoensis, or kurstaki have been reported to encode a cry3 gene [51,52]. Owing to the well-known activity in important coleopteran pests, such as Leptinotarsa decemlineata (Coleoptera: Chrysomelidae) or Diabrotica spp. (Coleoptera: Chrysomelidae), some of these isolates have been 
developed as bioinsecticides for beetle control [47]. Cry3Aa, Cry3Ba, Cry3Bb and Cry3Ca proteins have shown activity against most major coleopteran families, including Chrysomelidae, Curculionidae, Scarabaeidae, and Tenebrionidae, among others (Table 1). Although Cry3 proteins are the most effective Bt toxins against chrysomelid beetles, the widespread use of Cry3-based insecticides and Bt crops carries the risk of selecting insect biotypes tolerant to that proteins. The appearance of resistant populations of the chrysomelids L. decemlineata, Chrysomela scripta under laboratory conditions or Diabrotica spp. to Bt maize have been reported [53-55].

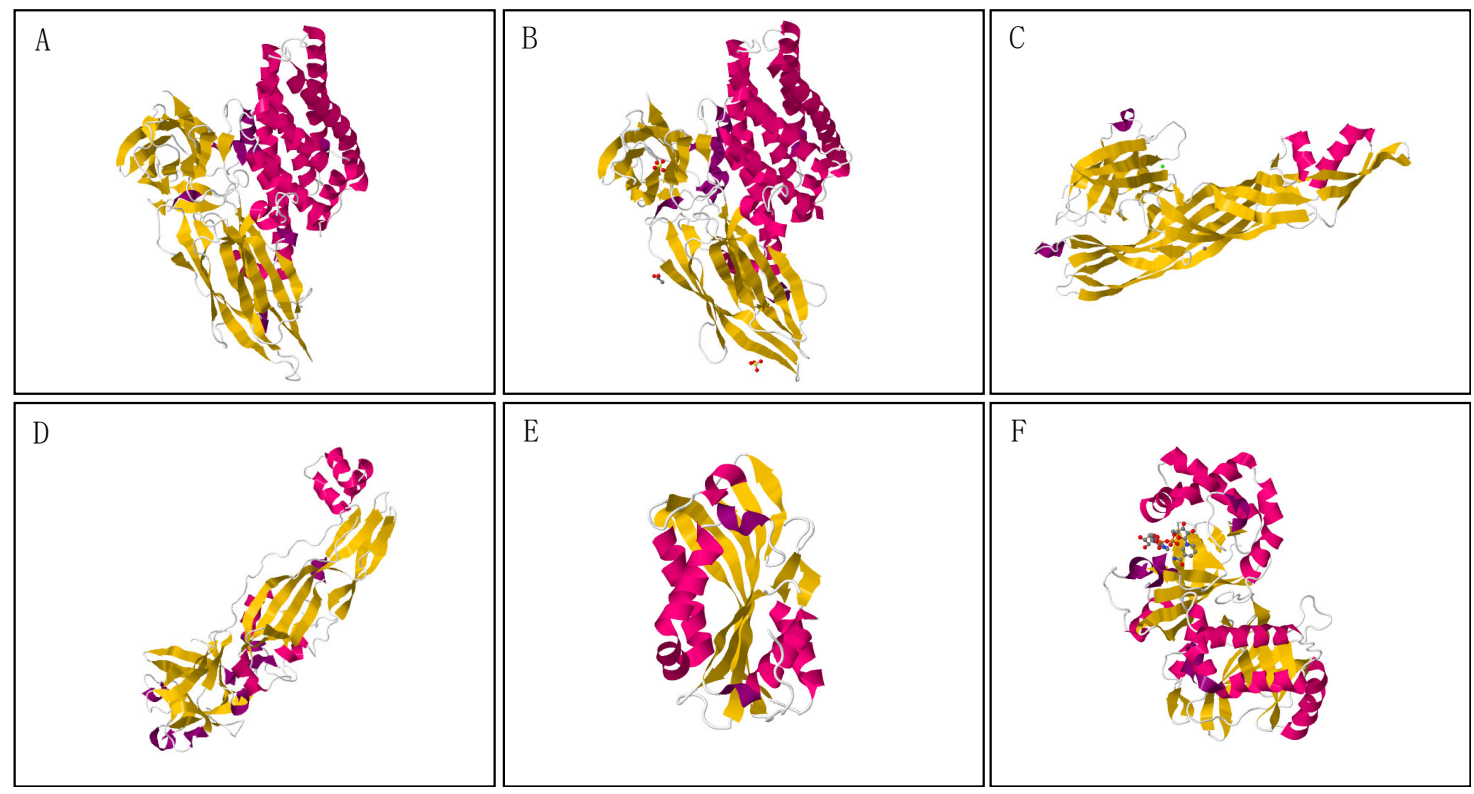

Figure 3. Bacillus thuringiensis proteins, with particular activity against coleopteran pests, for which three-dimensional structure has been predicted. (A) Cry3Aa (PBD accession number 4QX1); (B) Cry8Ea (PBD accession number 3EB7); (C) Protein complex Cry23Aa/Cry37Aa (PBD accession number 4RHZ); (D) Binary proteins Cry34Ab and Cry35Ab (PBD accession number 4JOX and 4JPO); (E) Cyt1Aa (PBD accession number 3RON); (F) Secretable protein Vip2Aa with a NAD complex (PBD accession number 1QS2).

Cry7 and Cry8 groups are comparatively less active on chrysomelids, but they represent a serious alternative to Cry3 proteins. Cry7Aa, formerly known as CryIIIC, is very toxic to Cylas species (Coleoptera: Brentidae) [56], even more than Cry3 protein, but it has no negative effects against Anthonomus grandis (Coleoptera: Curculionidae) or D. undecimpuntata [52]. Moreover, toxicity to Colorado potato beetle has been reported, but only after in vitro solubilization [52], which was countered by a recent report of a Cry7Aa-type protoxin which is active against L. decemlineata without any previous solubilization step [57]. Solubilized Cry7Ab is active against Henosepilachna vigintiomaculata (Coleoptera: Coccinellidae) and Acanthoscelides obtectus (Coleoptera: Chrysomelidae), but not against Anomala corpulenta (Coleoptera: Scarabaeidae) or Pyrrhalta aenescens (Coleoptera: Chrysomelidae) [57,58]. Cry8-type proteins are toxic to a large number of coleopteran pests, particularly against species in the Scarabaeidae family [59-61]. Furthermore, Cry8A and Cry8B proteins have shown activity against the chrysomelids L. decemlineata and Diabrotica spp., Cry8Ca against the tenebrionid Alphitobius diaperinus (Coleoptera: Tenebrionidae) [62] and Cry8Ka against the curculionid A. grandis [63]. Moreover, some Cry8 proteins, such as Cry8Ea, Cry8Ga or Cry8Na, are very specific, showing different activities against very closely related host species $[64,65]$. Cry6 Aa and Cry6Ba are active against the curculionid beetles Hypera postica and Hypera brunipennis, two of the more important pests in alfalfa $[66,67]$, as well as D. virgifera, which is susceptible to the activated toxin. Cry22 proteins also have activity to a wide spectrum of coleopteran insects. In particular, Cry22A 
and Cry22B proteins are toxic to coleopterans of the Brentidae, Chrysomelidae and Curculionidae families $[56,68,69]$.

Generally, Bt protein groups are particularly toxic to a certain insect order. However, some proteins may be active against different orders [70]. Mainly lepidopteran proteins Cry1Ba and Cry1Ia have shown activity against the key coleopteran pests $A$. grandis, A. obctetus, C. scripta and L. decemlineata [71-76]. Dual activity against Lepidoptera-Coleoptera has also been demonstrated by Cry9-type proteins. Cry9 toxins exhibit strong activity against main lepidopteran pests, but Cry9Da is also toxic against the scarab Anomala cuprea [77]. Other example of cross-order toxicity is depicted by the dipteran toxin Cry10Aa, which can kill the Cotton boll weevil (A. grandis) [78]. Additionally, Cry51Aa is toxic against Lygus spp. (Hemiptera) and L. decemlineata [79] and Cry55Aa, a typical nematicidal protein, has been reported as toxic to the chrysomelid Phyllotreta cruciferae [80].

Binary toxins, structurally different from classical 3-domain Cry proteins [25], used to be considered as single toxins because both proteins are required to kill their target. To date, two binary complex toxins have been proposed to have activity against beetles. The coleopteran specific Cry23Aa has been assayed together with Cry37Aa protein to kill Popillia japonica (Coleoptera: Sacarabaeidae) and Tribolium castaneum (Coleoptera: Tenebrionidae) [37]. Furthermore, this protein mixture has been found to be active against Cylas spp. (Coleoptera: Brentidae) and A. obtectus [56,75]. On the other hand, Cry34 protein is only active in association with Cry35 protein [17]. Cry34 and Cry35 are closely related and are often encoded in the same operon, with coordinated function and appearance in crystals $[40,81]$. The Cry34/Cry35 binary proteins are mainly active against corn rootworms and have been developed for in-plant control in Bt maize [40,82].

B. thuringiensis Cyt proteins have an in vitro cytolytic (hemolytic) activity, hence their name, and show predominant dipteran specificity [24]. However, some of them are also toxic to coleopteran pests, such as Cyt1Aa to C. scripta [72] or Cyt2Ca to the chrysomelids L. decemlineata and Diabrotica spp. [83] and the curculionid Diaprepes abbreviates (Coleoptera: Curculionidae) [84,85]. Besides, Cyt proteins improve the activity of Cry proteins. For instance, Cyt1Aa is able to overcome high levels of resistance to Cry3Aa by C. Scripta, playing an important role in resistance management [72].

Table 1. Insecticidal activity of Cry and Cyt proteins against coleopteran pests.

\begin{tabular}{|c|c|c|c|c|c|}
\hline \multirow{2}{*}{ Crystal Type Toxin } & \multicolumn{2}{|c|}{ Target Insect } & \multirow{2}{*}{ Activity $^{(a)}$} & \multirow{2}{*}{$\mathrm{LC}_{50}(\mathrm{~b})$} & \multirow{2}{*}{ Reference } \\
\hline & Scientific Name & Family & & & \\
\hline \multirow[t]{4}{*}{ Cry1Aa } & Anoplophora glabripennis & Cerambycidae & $\mathrm{N}$ & & [86] \\
\hline & Apriona germari & Cerambycidae & $\mathrm{N}$ & & [87] \\
\hline & Epilachna varivestis & Coccinellidae & A & & [88] \\
\hline & Tribolium castaneum & Tenebrionidae & LA & & [89] \\
\hline \multirow[t]{10}{*}{ Cry1Ab } & Diabrotica undecimpuntata & Chrysomelidae & $\mathrm{N}$ & & [90] \\
\hline & Leptinotarsa decemlineata & Chrysomelidae & $\mathrm{N}$ & & [90] \\
\hline & Phyllotreta armoraciae & Chrysomelidae & $\mathrm{N}$ & & [90] \\
\hline & Adalia bipunctata & Coccinellidae & $\mathrm{N}$ & & [91] \\
\hline & Atheta coriaria & Coccinellidae & $\mathrm{N}$ & & [91] \\
\hline & Cryptolaemus montrouzieri & Coccinellidae & $\mathrm{N}$ & & [91] \\
\hline & Harmonia axyridis & Coccinellidae & $\mathrm{N}$ & & [92] \\
\hline & Anthonomus grandis & Curculionidae & $\mathrm{N}$ & & [90] \\
\hline & Hypera postica & Curculionidae & $\mathrm{N}$ & & [90] \\
\hline & Popillia japonica & Scarabaeidae & $\mathrm{N}$ & & [90] \\
\hline \multirow[t]{9}{*}{ Cry1Ac } & Diabrotica undecimpuntata & Chrysomelidae & $\mathrm{N}$ & & [90] \\
\hline & Leptinotarsa decemlineata & Chrysomelidae & $\mathrm{N}$ & & [90] \\
\hline & Phyllotreta armoraciae & Chrysomelidae & $\mathrm{N}$ & & [90] \\
\hline & Hippodamia convergens & Coccinellidae & $\mathrm{N}$ & & [93] \\
\hline & Anthonomus grandis & Curculionidae & $\mathrm{N}$ & & [90] \\
\hline & Hypera postica & Curculionidae & $\mathrm{N}$ & & {$[90,94]$} \\
\hline & Haptoncus luteolus & Nitidulidae & $\mathrm{N}$ & & [95] \\
\hline & Tribolium castaneum & Tenebrionidae & $\mathrm{N}$ & & [96] \\
\hline & Popillia japonica & Scarabaeidae & $\mathrm{N}$ & & {$[90]$} \\
\hline Cry1Ah & Propylea japónica & Coccinellidae & $\mathrm{N}$ & & [97] \\
\hline
\end{tabular}


Table 1. Cont.

\begin{tabular}{|c|c|c|c|c|c|}
\hline \multirow{2}{*}{ Crystal Type Toxin } & \multicolumn{2}{|l|}{ Target Insect } & \multirow{2}{*}{ Activity ${ }^{(a)}$} & \multirow{2}{*}{$\mathrm{LC}_{50}(\mathrm{~b})$} & \multirow{2}{*}{ Reference } \\
\hline & Scientific Name & Family & & & \\
\hline Cry1Aj & Harmonia axyridis & Coccinellidae & $\mathrm{N}$ & & [92] \\
\hline \multirow{9}{*}{ Cry1Ba } & Anoplophora glabripennis & Cerambycidae & $\mathrm{N}$ & & [86] \\
\hline & Acanthoscelides obtectus & Chrysomelidae & A & & [75] \\
\hline & Chrysomela scripta $F$ & Chrysomelidae & A & $1.8 / / 5.9$ & {$[71,72]$} \\
\hline & Leptinotarsa decemlineata & Chrysomelidae & A & $1050 / / 142$ & {$[71,73]$} \\
\hline & Phaedon cochleariae & Chrysomelidae & $\mathrm{N}$ & & [98] \\
\hline & Anthonomus grandis & Curculionidae & A & 305.32 & [74] \\
\hline & Asymmathetes vulcanorum & Curculionidae & $\mathrm{N}$ & & [99] \\
\hline & Hypothenemus hampei & Curculionidae & A & & [100] \\
\hline & Tribolium castaneum & Tenebrionidae & $\mathrm{N}$ & & [89] \\
\hline Cry1Ca & Tribolium castaneum & Tenebrionidae & $\mathrm{N}$ & & [89] \\
\hline Cry1Da & Tribolium castaneum & Tenebrionidae & $\mathrm{N}$ & & [89] \\
\hline Cry1Ea & Tribolium castaneum & Tenebrionidae & $\mathrm{N}$ & & [89] \\
\hline \multirow[t]{2}{*}{ Cry1Fa } & Cryptolestes pusillus & Laemophloeidae & $\mathrm{N}$ & & [17] \\
\hline & Tribolium castaneum & Tenebrionidae & $\mathrm{N}$ & & [17] \\
\hline Cry1Fb & Tribolium castaneum & Tenebrionidae & $\mathrm{N}$ & & [89] \\
\hline \multirow[t]{9}{*}{ Cry1Ia } & Acanthoscelides obtectus & Chrysomelidae & A & & [75] \\
\hline & Agelastica coerulea & Chrysomelidae & $\mathrm{N}$ & & {$[101,102]$} \\
\hline & Diabrotica undecimpuntata & Chrysomelidae & $\mathrm{N}$ & & [103] \\
\hline & Leptinotarsa decemlineata & Chrysomelidae & A & $33.7 / / 10$ & {$[73,104]$} \\
\hline & Phaedom brassicae & Chrysomelidae & $\mathrm{N}$ & & [101] \\
\hline & Anthonomus grandis & Curculionidae & A & $21.5 / / 230$ & {$[76,105]$} \\
\hline & Asymmathetes vulcanorum & Curculionidae & $\mathrm{N}$ & & [99] \\
\hline & Tenebrio molitor & Tenebrionidae & $\mathrm{N}$ & & [106] \\
\hline & Tribolium castaneum & Tenebrionidae & $\mathrm{N}$ & & [89] \\
\hline \multirow[t]{2}{*}{ Cry1Ib } & Phaedom brassicae & Chrysomelidae & $\mathrm{N}$ & & [101] \\
\hline & Agelastica coerulea & Chrysomelidae & $\mathrm{N}$ & & [101] \\
\hline Cry1Id & Agelastica coerulea & Chrysomelidae & $\mathrm{N}$ & & [102] \\
\hline \multirow[t]{2}{*}{ Cry1Ie } & Ceratoma trifurcata & Chrysomelidae & $\mathrm{N}$ & & [107] \\
\hline & Pyrrhalta aenescens & Chrysomelidae & $\mathrm{N}$ & & [108] \\
\hline \multirow[t]{2}{*}{ Cry1Jb } & Diabrotica undecimpuntata & Chrysomelidae & $\mathrm{N}$ & & [109] \\
\hline & Leptinotarsa decemlineata & Chrysomelidae & $\mathrm{N}$ & & [109] \\
\hline \multirow[t]{5}{*}{ Cry2Aa } & Diabrotica undecimpuntata & Chrysomelidae & $\mathrm{N}$ & & [93] \\
\hline & Diabrotica virgifera & Chrysomelidae & $\mathrm{N}$ & & [93] \\
\hline & Leptinotarsa decemlineata & Chrysomelidae & $\mathrm{N}$ & & [93] \\
\hline & Hippodamia convergens & Coccinellidae & $\mathrm{N}$ & & [93] \\
\hline & Anthonomus grandis & Curculionidae & $\mathrm{N}$ & & [93] \\
\hline \multirow[t]{2}{*}{ Cry2Ab } & Propylea japonica & Coccinellidae & $\mathrm{N}$ & & [97] \\
\hline & Haptoncus luteolus & Nitidulidae & $\mathrm{N}$ & & [95] \\
\hline \multirow[t]{17}{*}{ Cry3Aa } & Rhyzophertha dominica & Bostrichidae & A & $1.17 \mu \mathrm{g} / \mathrm{mg}$ & [110] \\
\hline & Cylas brunneus & Brentidae & A & $1.88 \mu \mathrm{g} / \mathrm{g}$ & [56] \\
\hline & Cylas puncticollis & Brentidae & A & $1.99 \mu \mathrm{g} / \mathrm{g}$ & [56] \\
\hline & Apriona germari & Cerambycidae & A & & {$[94,111]$} \\
\hline & Acanthoscelides obtectus & Chrysomelidae & A & & {$[75]$} \\
\hline & Agelastica alni & Chrysomelidae & A & & [112] \\
\hline & Brontispa longissimi & Chrysomelidae & A & $0.475 \mathrm{mg} / \mathrm{mL}$ & [113] \\
\hline & Chrysomela tremulae & Chrysomelidae & A & & [114] \\
\hline & Chrysomela scripta $F$ & Chrysomelidae & A & & [115] \\
\hline & Chrysomela scripta $F$ & Chrysomelidae & A & $2.22 / / 1.8$ & {$[71,72]$} \\
\hline & Colaphellus bowringi & Chrysomelidae & A & $2.68 / / 1.33$ & {$[116,117]$} \\
\hline & Crioceris quaturdicerumpunctata & Chrysomelidae & A & 3.82 & [117] \\
\hline & Diabrotica undecimpuntata & Chrysomelidae & $\mathrm{N}$ & & {$[90,118]$} \\
\hline & Diabrotica virgifera & Chrysomelidae & $\mathrm{N}$ & & {$[118,119]$} \\
\hline & Leptinotarsa decemlineata & Chrysomelidae & A & $1.84 / / 3.56$ & {$[73,118]$} \\
\hline & Phaedom brassicae & Chrysomelidae & A & 1.11 & [117] \\
\hline & Phaedon cochleariae & Chrysomelidae & $\mathrm{A}$ & & [120] \\
\hline
\end{tabular}


Table 1. Cont.

\begin{tabular}{|c|c|c|c|c|c|}
\hline \multirow{2}{*}{ Crystal Type Toxin } & \multicolumn{2}{|l|}{ Target Insect } & \multirow{2}{*}{ Activity ${ }^{\text {(a) }}$} & \multirow{2}{*}{$\mathrm{LC}_{50}{ }^{(\mathrm{b})}$} & \multirow{2}{*}{ Reference } \\
\hline & Scientific Name & Family & & & \\
\hline & Phyllotreta armoraciae & Chrysomelidae & $\mathrm{N}$ & & [90] \\
\hline & Plagiodera versicolora & Chrysomelidae & A & $1.13 / / 3.09$ & [18] \\
\hline & Pyrrhalta aenescens & Chrysomelidae & A & $0.22 \mathrm{mg} / \mathrm{mL}$ & [121] \\
\hline & Pyrrhalta luteola & Chrysomelidae & A & $0.12 \mu \mathrm{g} / \mathrm{cm}^{2}$ & [49] \\
\hline & Adalia bipunctata & Coccinellidae & $\mathrm{N}$ & & [91] \\
\hline & Atheta coriaria & Coccinellidae & $\mathrm{N}$ & & [91] \\
\hline & Cryptolaemus montrouzieri & Coccinellidae & $\mathrm{N}$ & & [91] \\
\hline & Epilachna varivestis & Coccinellidae & A & & [88] \\
\hline & Anthonomus grandis & Curculionidae & $\mathrm{N}$ & & [90] \\
\hline & Asymmathetes vulcanorum & Curculionidae & $\mathrm{N}$ & & [99] \\
\hline & Hypera postica & Curculionidae & $\mathrm{N}$ & & [90] \\
\hline & Hypothenemus hampei & Curculionidae & $\mathrm{A}$ & & [100] \\
\hline & Myllocerus undecimpustulatus & Curculionidae & A & $152 \mathrm{ng} / \mathrm{cm}^{2}$ & [122] \\
\hline & Premnotrypes vorax & Curculionidae & LA & & [123] \\
\hline & Sitophilus oryzae & Curculionidae & A & & [124] \\
\hline & Amphimallon solstitiale & Scarabaeidae & $\mathrm{A}$ & & [112] \\
\hline & Anomala corpulenta & Scarabaeidae & $\mathrm{N}$ & & [116] \\
\hline & Melontha melontha & Scarabaeidae & A & & [112] \\
\hline & Popillia japonica & Scarabaeidae & $\mathrm{N}$ & & [90] \\
\hline & Alphitobius diaperinus & Tenebrionidae & A & $9.58 / / 8 \mu \mathrm{g} / \mathrm{cm}^{2}$ & {$[62,125]$} \\
\hline & Tribolium castaneum & Tenebrionidae & $\mathrm{N}$ & & {$[96,110]$} \\
\hline & Tribolium castaneum & Tenebrionidae & A & $0.46 \mathrm{~g} / 10 \mathrm{~g}$ & [89] \\
\hline & Tenebrio molitor & Tenebrionidae & A & $11.4 \mu \mathrm{g} /$ larve & [126] \\
\hline & Tenebrio molitor & Tenebrionidae & A & & {$[110,127]$} \\
\hline \multirow[t]{9}{*}{ Cry3Ba } & Cylas brunneus & Brentidae & A & $1.304 \mu \mathrm{g} / \mathrm{g}$ & [56] \\
\hline & Cylas puncticollis & Brentidae & A & $1.273 \mu \mathrm{g} / \mathrm{g}$ & [56] \\
\hline & Chrysomela scripta $F$ & Chrysomelidae & A & & [115] \\
\hline & Diabrotica undecimpuntata & Chrysomelidae & $\mathrm{A}$ & $107 \mathrm{ng} / \mathrm{mm}^{2}$ & [128] \\
\hline & Leptinotarsa decemlineata & Chrysomelidae & A & $1.35 \mathrm{ng} / \mathrm{mm}^{2}$ & [128] \\
\hline & Epilachna varivestis & Coccinellidae & $\mathrm{N}$ & & [88] \\
\hline & Popillia japonica & Scarabaeidae & A & 1 & [37] \\
\hline & Tribolium castaneum & Tenebrionidae & A & $1.60 \mathrm{~g} / 10 \mathrm{~g}$ & [89] \\
\hline & Tribolium castaneum & Tenebrionidae & A & $13.55 \mathrm{mg} / \mathrm{mL}$ & {$[37,96]$} \\
\hline \multirow[t]{7}{*}{ Cry3Bb } & Cylas brunneus & Brentidae & A & $1.83 \mu \mathrm{g} / \mathrm{g}$ & [56] \\
\hline & Cylas puncticollis & Brentidae & A & $1.82 \mu \mathrm{g} / \mathrm{g}$ & [56] \\
\hline & Anoplophora glabripennis & Cerambycidae & $\mathrm{N}$ & & [86] \\
\hline & Diabrotica undecimpuntata & Chrysomelidae & A & $9.49 / / 1.18$ & {$[118,129]$} \\
\hline & Diabrotica virgifera & Chrysomelidae & A & $2.10 / / 5.18$ & {$[118,129]$} \\
\hline & Leptinotarsa decemlineata & Chrysomelidae & A & $6.86 / / 6.54$ & {$[118,129]$} \\
\hline & Alphitobius diaperinus & Tenebrionidae & A & $26.52 / / 50 \mu \mathrm{g} / \mathrm{cm}^{2}$ & {$[62,125]$} \\
\hline \multirow[t]{4}{*}{ Cry3Ca } & Cylas brunneus & Brentidae & A & $0.69 \mu \mathrm{g} / \mathrm{g}$ & [56] \\
\hline & Cylas puncticollis & Brentidae & A & $0.57 \mu \mathrm{g} / \mathrm{g}$ & [56] \\
\hline & Leptinotarsa decemlineata & Chrysomelidae & A & $0.7 / / 320.13$ & {$[130,131]$} \\
\hline & Tribolium castaneum & Tenebrionidae & $\mathrm{N}$ & & [96] \\
\hline \multirow[t]{3}{*}{ Cry6Aa } & Diabrotica virgifera & Chrysomelidae & A & $77 \mu \mathrm{g} / \mathrm{cm}^{2}$ & {$[66,119]$} \\
\hline & Hypera brunneipennis & Curculionidae & A & & [66] \\
\hline & Hypera postica & Curculionidae & A & & [66] \\
\hline Cry6Ba & Hypera postica & Curculionidae & A & $280 \mathrm{ng} / \mu \mathrm{L}$ & [94] \\
\hline \multirow[t]{6}{*}{ Cry7Aa } & Cylas brunneus & Brentidae & A & $0.44 \mu \mathrm{g} / \mathrm{g}$ & [56] \\
\hline & Cylas puncticollis & Brentidae & A & $0.34 \mu \mathrm{g} / \mathrm{g}$ & [56] \\
\hline & Anoplophora glabripennis & Cerambycidae & $\mathrm{N}$ & & [86] \\
\hline & Diabrotica undecimpuntata & Chrysomelidae & $\mathrm{N}$ & & [52] \\
\hline & Leptinotarsa decemlineata & Chrysomelidae & A & $13.1 / / 18.8$ & {$[52,57]$} \\
\hline & Anthonomus grandis & Curculionidae & $\mathrm{N}$ & & [52] \\
\hline
\end{tabular}


Table 1. Cont.

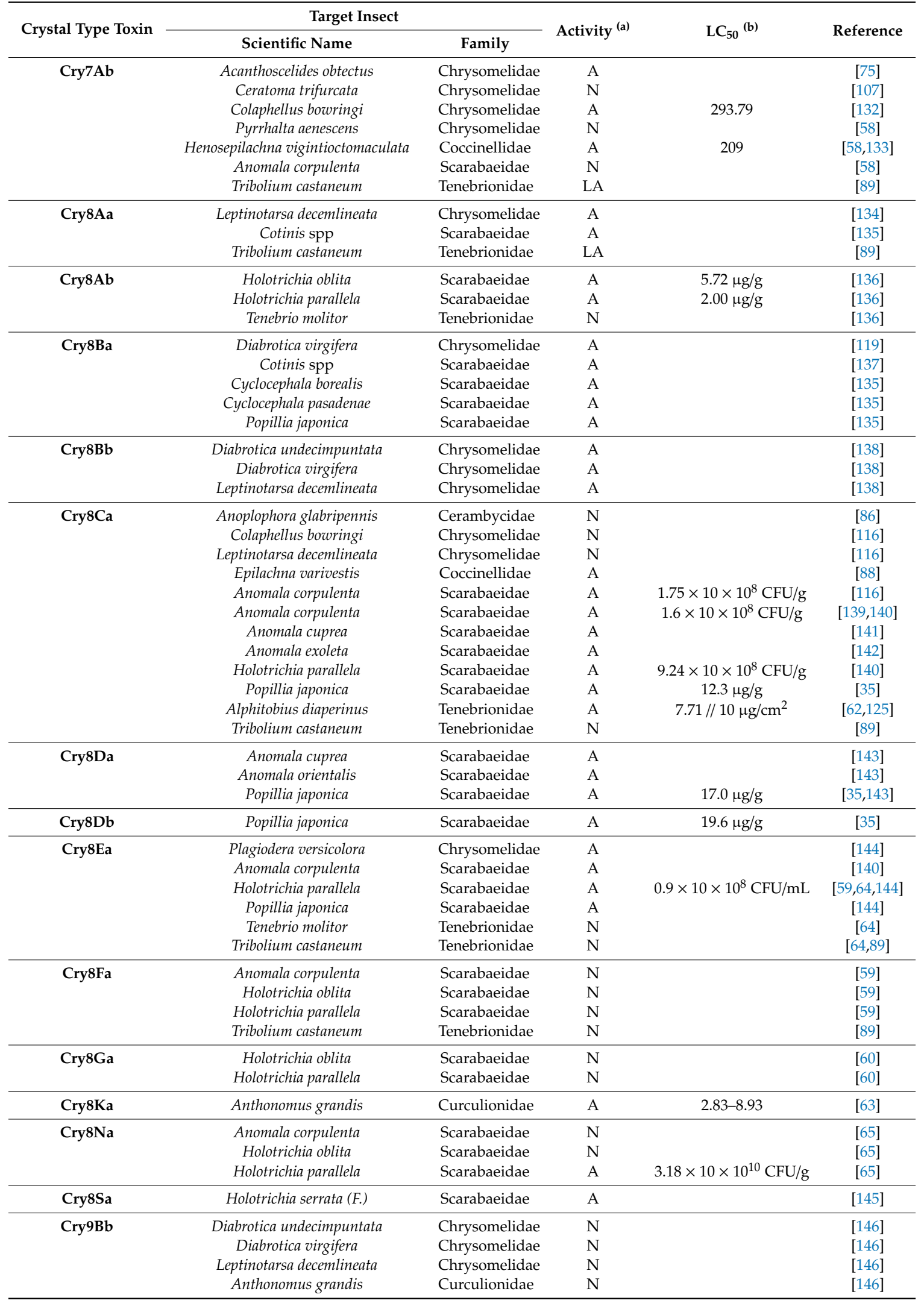


Table 1. Cont

\begin{tabular}{|c|c|c|c|c|c|}
\hline \multirow{2}{*}{ Crystal Type Toxin } & \multicolumn{2}{|c|}{ Target Insect } & \multirow{2}{*}{ Activity ${ }^{(a)}$} & \multirow{2}{*}{$\mathrm{LC}_{50}{ }^{(\mathrm{b})}$} & \multirow{2}{*}{ Reference } \\
\hline & Scientific Name & Family & & & \\
\hline \multirow[t]{2}{*}{ Cry9Da } & Anomala cuprea & Scarabaeidae & $\mathrm{A}$ & & [77] \\
\hline & Tribolium castaneum & Tenebrionidae & $\mathrm{N}$ & & [89] \\
\hline Cry10Aa & Anthonomus grandis & Curculionidae & $\mathrm{A}$ & 7.12 & [78] \\
\hline Cry14Aa & Tribolium castaneum & Tenebrionidae & LA & & [89] \\
\hline Cry15Aa & Leptinotarsa decemlineata & Chrysomelidae & $\mathrm{N}$ & & [147] \\
\hline Cry18Aa1 & Melontha melontha & Scarabaeidae & A & & [148] \\
\hline \multirow[t]{2}{*}{ Cry22Aa } & Anthonomus grandis & Curculionidae & A & $0.75 \mu \mathrm{g} /$ well & [68] \\
\hline & Tribolium castaneum & Tenebrionidae & A & $1.25 \mathrm{~g} / 10 \mathrm{~g}$ & [89] \\
\hline \multirow[t]{6}{*}{ Cry22Ab } & Cylas brunneus & Brentidae & A & $1.01 \mu \mathrm{g} / \mathrm{g}$ & [56] \\
\hline & Cylas puncticollis & Brentidae & A & $0.78 \mu \mathrm{g} / \mathrm{g}$ & [56] \\
\hline & Diabrotica virgifera & Chrysomelidae & A & $39.4 \mathrm{\mu g} / \mathrm{cm}^{2}$ & [69] \\
\hline & Diabrotica undecimpuntata & Chrysomelidae & $\mathrm{N}$ & & [69] \\
\hline & Leptinotarsa decemlineata & Chrysomelidae & $\mathrm{N}$ & & [69] \\
\hline & Anthonomus grandis & Curculionidae & A & $3.12 \mu \mathrm{g} /$ well & [68] \\
\hline \multirow[t]{2}{*}{ Cry22Ba } & Diabrotica virgifera & Chrysomelidae & $\mathrm{N}$ & & [68] \\
\hline & Anthonomus grandis & Curculionidae & A & & [68] \\
\hline \multirow[t]{6}{*}{ Cry23Aa/37Aa } & Cylas brunneus & Brentidae & A & $0.46 \mu \mathrm{g} / \mathrm{g}$ & [56] \\
\hline & Cylas puncticollis & Brentidae & A & $0.42 \mu \mathrm{g} / \mathrm{g}$ & [56] \\
\hline & Acanthoscelides obtectus & Chrysomelidae & A & & [75] \\
\hline & Anthonomus grandis & Curculionidae & A & & [149] \\
\hline & Popillia japonica & Scarabaeidae & A & & {$[37]$} \\
\hline & Tribolium castaneum & Tenebrionidae & A & $6.30 \mu \mathrm{g} \mathrm{SC} / \mu \mathrm{L}$ & {$[37,61]$} \\
\hline Cry34Aa & Diabrotica virgifera & Chrysomelidae & $\mathrm{N}$ & & [40] \\
\hline \multirow[t]{2}{*}{ Cry34Ab } & Diabrotica undecimpuntata & Chrysomelidae & LA & & [150] \\
\hline & Diabrotica virgifera & Chrysomelidae & $\mathrm{N}$ & & {$[40,82]$} \\
\hline Cry34Ac & Diabrotica virgifera & Chrysomelidae & $\mathrm{N}$ & & [40] \\
\hline \multirow[t]{2}{*}{ Cry34Aa/35Aa } & Diabrotica undecimpuntata & Chrysomelidae & $\mathrm{A}$ & $34.1 \mu \mathrm{g} /$ well & [151] \\
\hline & Diabrotica virgifera & Chrysomelidae & A & $34 \mathrm{\mu g} / \mathrm{cm}^{2}$ & {$[81,151]$} \\
\hline \multirow[t]{9}{*}{ Cry34Ab/35Ab } & Rhyzophertha dominica & Bostrichidae & $\mathrm{N}$ & & [17] \\
\hline & Diabrotica undecimpuntata & Chrysomelidae & A & & [150] \\
\hline & Diabrotica virgifera & Chrysomelidae & A & $3 \mu \mathrm{g} / \mathrm{cm}^{2}$ & {$[40,81]$} \\
\hline & Oryzaephilus surinamensis & Cucujidae & LA & & [17] \\
\hline & Sitophilus oryzae & Curculionidae & LA & & [17] \\
\hline & Trogoderma variabile & Dermestidae & $\mathrm{N}$ & & [17] \\
\hline & Tenebrio molitor & Tenebrionidae & LA & & [17] \\
\hline & Tribolium castaneum & Tenebrionidae & LA & & [17] \\
\hline & Tribolium castaneum & Tenebrionidae & $\mathrm{N}$ & & [96] \\
\hline Cry34Ac/35Ac & Diabrotica virgifera & Chrysomelidae & A & $7 \mu \mathrm{g} / \mathrm{cm}^{2}$ & {$[40,81]$} \\
\hline Cry34Ba/35Ba & Diabrotica virgifera & Chrysomelidae & A & & [39] \\
\hline Cry35Aa & Diabrotica virgifera & Chrysomelidae & $\mathrm{N}$ & & [40] \\
\hline Cry35Ab & Diabrotica virgifera & Chrysomelidae & $\mathrm{N}$ & & {$[40,82]$} \\
\hline Cry35Ac & Diabrotica virgifera & Chrysomelidae & $\mathrm{N}$ & & [40] \\
\hline Cry36A & Diabrotica virgifera & Chrysomelidae & A & $147.3 \mu \mathrm{g} /$ well & [151] \\
\hline Cry37Aa & Tribolium castaneum & Tenebrionidae & $\mathrm{A}$ & $1.25 \mathrm{~g} / 10 \mathrm{~g}$ & [89] \\
\hline Cry38Aa & Diabrotica virgifera & Chrysomelidae & $\mathrm{N}$ & & [39] \\
\hline Cry43Aa & Anomala cuprea & Scarabaeidae & A & & [152] \\
\hline Cry43Ba & Anomala cuprea & Scarabaeidae & $\mathrm{N}$ & & [152] \\
\hline \multirow[t]{4}{*}{ Cry51Aa } & Diabrotica undecimpuntata & Chrysomelidae & $\mathrm{N}$ & & [79] \\
\hline & Diabrotica virgifera & Chrysomelidae & $\mathrm{N}$ & & [79] \\
\hline & Leptinotarsa decemlineata & Chrysomelidae & A & & [79] \\
\hline & Tribolium castaneum & Tenebrionidae & A & $1.45 \mathrm{~g} / 10 \mathrm{~g}$ & [89] \\
\hline
\end{tabular}


Table 1. Cont.

\begin{tabular}{|c|c|c|c|c|c|}
\hline \multirow{2}{*}{ Crystal Type Toxin } & \multicolumn{2}{|c|}{ Target Insect } & \multirow{2}{*}{ Activity ${ }^{(a)}$} & \multirow{2}{*}{$\mathrm{LC}_{50}(\mathrm{~b})$} & \multirow{2}{*}{ Reference } \\
\hline & Scientific Name & Family & & & \\
\hline \multirow[t]{2}{*}{ Cry55Aa } & Phyllotreta cruciferae & Chrysomelidae & $\mathrm{A}$ & & [80] \\
\hline & Tribolium castaneum & Tenebrionidae & $\mathrm{N}$ & & [89] \\
\hline Cyt1Aa & Chrysomela scripta $F$ & Chrysomelidae & A & 132.6 & [72] \\
\hline \multirow[t]{6}{*}{ Cyt2Ca } & Diabrotica undecimpuntata & Chrysomelidae & $\mathrm{A}$ & $25 \mu \mathrm{g} /$ well & [83] \\
\hline & Diabrotica virgifera & Chrysomelidae & A & $10.8 \mu \mathrm{g} /$ well & [83] \\
\hline & Leptinotarsa decemlineata & Chrysomelidae & A & & [83] \\
\hline & Diapepes abbreviatus & Curculionidae & $\mathrm{A}$ & 50.7 & {$[84,85]$} \\
\hline & Popillia japonica & Scarabaeidae & A & & [83] \\
\hline & Tribolium castaneum & Tenebrionidae & A & & [83] \\
\hline
\end{tabular}

(a) The parameter is mortality. $\mathrm{A}=$ active; $\mathrm{N}=$ not active; $\mathrm{LA}=$ low activity, with significant inhibition of growth;

(b) $\mathrm{LC}_{50}=$ lethal concentration that causes $50 \%$ mortality of the insects. Data are expressed in $\mu \mathrm{g} / \mathrm{mL}$, unless otherwise

stated. "//" separate two different values of the $\mathrm{LC}_{50}$.

\subsubsection{Genetically Engineered Cry Genes}

Recent advances in next generation sequencing and genetic engineering technologies allow the construction of new synthetic cry genes that increase or amplify their toxicity. The domain regions of some lepidopteran-specific proteins have been modified in an attempt to improve their specific activity or broaden their host range $[15,153]$. The first coleopteran hybrid protein was made by fusing the sequences located in domain III of the $c r y 3 A$ and $c r y 1 A a$ genes, although unfortunately, it caused the loss of activity against L. decemlineata [154]. Nonetheless, substituting domain III of Cry3Aa with the same domain from Cry1 Ab induced activity against WCR (Western corn rootworm) larvae [155]. On a different approach, a cry3Bb1 gene was engineered with five amino acid substitutions to produce the new Cry3Bb1.11098 protein, which increased the activity of the natural protein against WCR [156]. Similarly, a Cry3A variant (eCry3.1Ab) was designed to confer novel activity against rootworms by creating a cathepsin $\mathrm{G}$ protease recognition site [157]. This technology has been introduced successfully in the development of transgenic plants, mainly to overcome the appearance of resistance by WCR populations [158].

\subsection{Mode of Action}

The mode of action has been mostly studied in lepidopteran insects, although it is believed to be similar between different insect orders, with some peculiarities [8]. Briefly, it is widely accepted that the process begins once the target insect ingests the protein and reaches the insect midgut, where it is solubilized and proteolytically activated. Such an activation allows toxins to first bind to their specific receptors in the host cell membrane, then to their oligomerization and, eventually, to the formation of pores in the cell membrane (Figure 4). In this multi-step mode of action, several factors may contribute to protein specificity [159].

\subsubsection{Solubilization and Proteolytic Processing}

Once proteins reach the host midgut, they are released from their crystal package to initiate the pathogenic process. The crystals are stabilized by disulfide bridges among the C-terminal ends of the protoxins. More recently, the occurrence of $20 \mathrm{kbp}$ DNA fragments with protoxins and 100-300 pb DNA fragments with in vitro proteolytic activated toxins has been established [160]. These DNA fragments have been observed to be associated with different Bt-toxins as Cry1A, Cry2A, etc., however, they have been more extensively studied on Cry8 toxins [21]. The sequence of the DNA fragments is not specific and they are located in plasmids and chromosomes [161]. Bioinformatics modelling suggests that two protoxin regions bind to major grooves and another one, combined with phosphoric acid, binds to the minor groove [162]. The associated DNA should be eliminated by the DNAses in the insect gut for the correct protein activation. In fact, DNA-protein association impairs the specific binding [163]. 


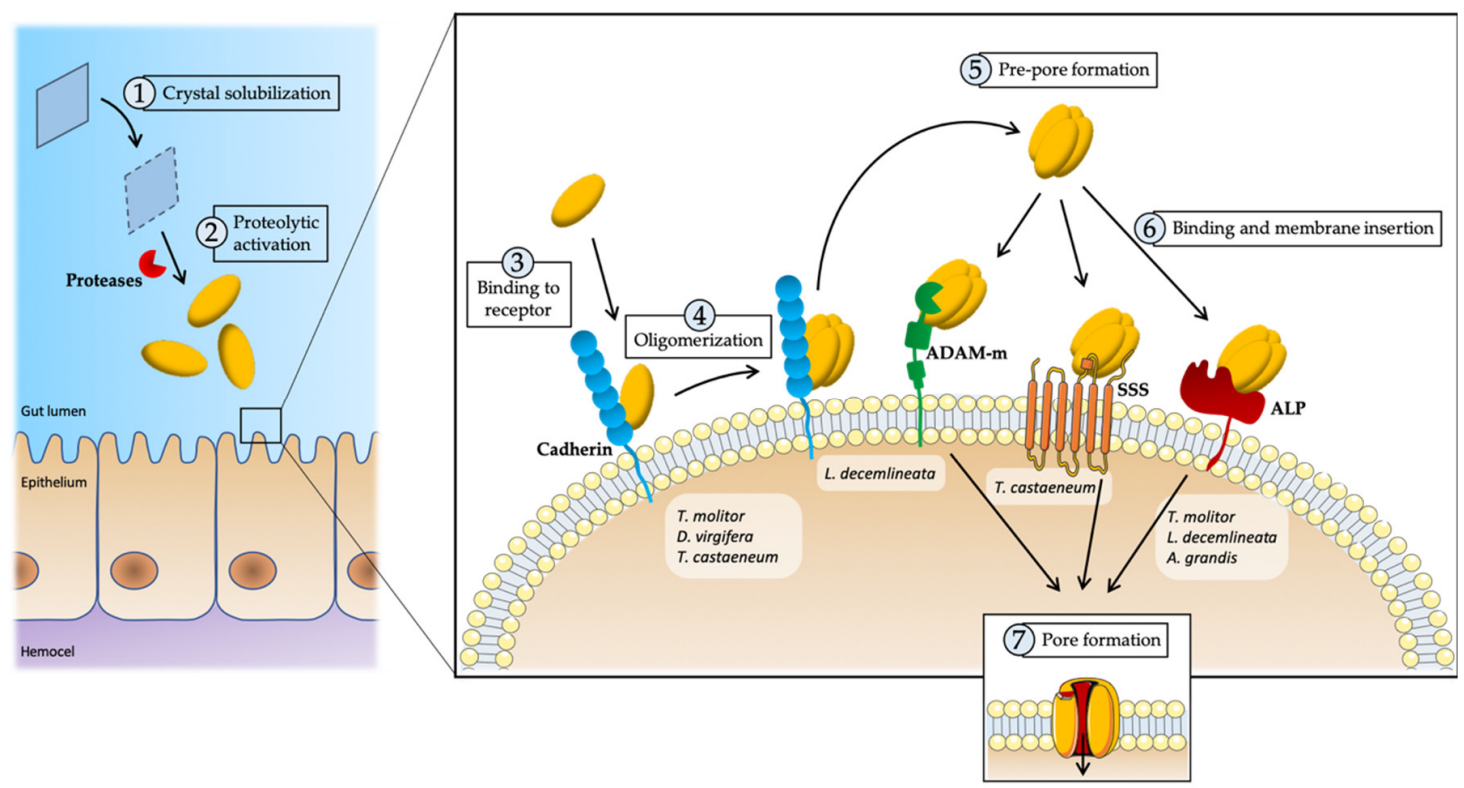

Figure 4. Schematic representation of the particularities in the mechanism of action of crystal proteins against coleopteran pests. (1) Crystal solubilizes in the acidic conditions of the coleopteran midgut lumen and (2) activates into toxin by proteolytic processing of the protoxin by the specific digestive enzymes, specially cysteine and aspartic proteases. (3) Toxins are able to bind to a first receptor (CADR), (4) oligomerizate and (5) form an oligomeric pre-pore structure that (6) is able to bind to a second specific receptor (ADAM metalloproteases/GPI-anchored alkaline phosphatases/sodium solute symporters). This event induces the insertion into the membrane, leading to (7) pore formation and finally to cell lysis.

It is well accepted that solubilization processes are due to the environmental conditions in the susceptible insect midgut, mainly to $\mathrm{pH}$ values. Of note, unlike the alkaline midgut of lepidopteran and dipteran insects, beetles have an acidic midgut, suggesting that different solubilization conditions are needed for each protein [164]. For instance, the midgut fluids of L. decemlineata and D. virgifera larvae do not seem to solubilize Cry1B and Cry7Aa1, and only after a previous in vitro solubilization, these proteins become active [52,71]. However, recent reports show that Cry7Ab2 and Cry7Aa2 proteins solubilize into midgut fluids of $H$. vigintioctomaculata and $L$. decemlineata larvae, respectively, suggesting that the lack of solubilization involves more factors than $\mathrm{pH}[57,58]$. Cyt proteins dissolve readily under alkaline conditions, especially at $\mathrm{pH} 8$ or higher, and they are harder to solubilize in neutral or slightly acidic pHs, which occurs in coleopteran midguts [72]. Another example of the importance of crystal solubilization was published by Galitsky et al. [28]. They related that differences in toxin solubility, oligomerization and binding for the Cry3-type toxins, in addition to differences in domain III, might explain the different specificities of Cry3A and Cry3B (e.g., WCR is susceptible to Cry3Bb1 but not to Cry3A). Solubilized proteins are proteolytically activated by gut proteases, which generate the toxic three-domain fragment of about $65 \mathrm{kDa}$ [33]. In Lepidoptera and Diptera species, the main proteases present in the alkaline midgut juices are serine proteases, especially trypsin and chymotrypsin proteases [165]. However, the coleopteran species use digestive proteases belonging to cysteine and aspartic proteases and serine proteases are only present in some cases [166]. The presence of different proteases may be an important factor in toxin activation specificity, and improper processing of $\mathrm{Bt}$ toxins can involve the development of insect resistances. It has been reported that the combination of Cry3Aa protein and certain protease inhibitors enhances the toxicity against Rhyzopertha dominica (Coleoptera: Bostrichidae) larvae, evidencing that protease inhibitors may play an important role in resistant pests management [110]. Moreover, the relevance of a nicking in the $\mathrm{N}$-terminal end, in the alpha 1-3 of Domain I in the activated Cry3A and Cry8Da toxins, has been shown, which rendered an $8 \mathrm{kDa}$ fragment to obtain a functional $54 \mathrm{kDa}$ toxin for receptor binding [167]. 


\subsubsection{Binding to the Larval Epithelium}

The activated toxin is able to bind to specific receptors located in the midgut epithelial cells to form an oligomeric pre-pore structure and alterations in the midgut receptors is a critical step for insect resistance appearance [159]. It has been demonstrated that Cry3Ba protein shares a binding receptor with Cry3Aa and Cry3Ca proteins, although heterologous-competition experiments show that both proteins may have other binding sites and only share one with Cry3Ba3 [168]. It has also been shown that Cry3Bb, Cry3Ca and Cry7Aa proteins competed for the same binding sites in C. puncticollis, so a mutation in the midgut receptor could render all three proteins ineffective [169]. To date, several specific coleopteran binding proteins have been identified. It has been shown that an ADAM metalloprotease can be considered as a Cry3Aa receptor in L. decemlineata, and this binding interaction improves Cry3Aa pore-formation [170]. GPI-anchored alkaline phosphatases (ALP) are also important for the Cry3Aa binding to Tenebrio molitor brush border membrane vesicles (BBMV) and are highly expressed when larvae are exposed to Cry3Aa [171]. In the same way, the Cry1Ba toxin binds to ALPs from A. grandis midgut cells [74]. Although some putative cadherines have been previously described [172,173], Fabrick et al. [127] were the first authors reporting a cadherin protein (TmCad1), cloned from T. molitor larval midgut as a Cry3Aa binding receptor. Furthermore, injection of TmCad1 dsRNA into T. molitor larvae conferred resistance to Cry3Aa. Another truncated cadherin protein (DvCad1-CR8-10), isolated from the WCR, binds to activated Cry3Aa, Cry3Bb [118] and also Cry8Ca [62], enhancing the activity of L. decemlineata, Diabrotica spp. and A. diaperinus. Finally, in T. castaeneum larvae, a cadherine (TcCad1) and a sodium solute symporter (TcSSS) have been identified as putative Cry3Ba functional receptors, determinant for the specific Cry protein toxicity against coleopterans [174].

Studied Cry8-binding proteins revealed a difference from those confirmed previously as receptors for Cry1A or Cry3A proteins in lepidopteran and coleopteran insect species, such as aminopeptidases, cadherins or ABCC transporters $[175,176]$. A Cry8-like toxin without the C-terminal end has been described, which completely shared binding sites with Cry8Ga, despite only sharing $30 \%$ of the sequence, in Holotrichia oblita. Cry8Da tested on Popillia japonica BBMV, bound specifically with a $150 \mathrm{kDa}$ membrane protein which shared homology with coleopteran $\beta$-glucosidases [177]. Cry8E and Cry8-like toxins showed, in $\mathrm{H}$. parallela and $\mathrm{H}$. oblita, binding to several different proteins. The most relevant for both insect species and Cry8 proteins were serine proteases, sodium/potassium-transporting proteins, and a transferrin-like protein $[177,178]$.

There is evidence that some proteins work together to cause mortality in certain coleopteran species, although the mechanism of interaction between them remains unclear. In this way, it is hypothesized that Cry37 protein may facilitate linkage of channel-forming Cry23 toxin, given their homology to other binding proteins [24]. Moreover, the fact that Cry34Ab has some activity against the Western corn rootworm (WCR) on its own [150] seems to indicate that Cry35 has the role as a receptor of Cry34, which is mainly responsible for toxicity. Cyt proteins enhancing the insecticide potency of certain Cry toxins has been also observed. The Cyt1Aa protein, from Bt sub. israelensis, increases the activity of Cry11Aa toxin by acting as a membrane receptor [178]. Cyt1A also helps to overcome high levels of Cry3A resistance against C. scripta larvae [72]. Although this mechanism of action has not yet been elucidated, Cyt1A may act as a receptor of Cry3A to enhance the binding of this protein. This synergism between Cry and Cyt toxins is an excellent strategy to decrease the appearance of resistance to Cry proteins.

\subsubsection{Oligomerization and Pore Formation}

Although it remains unclear, some studies suggest that activated toxins need to form an oligomeric structure before insertion to the membrane as a result of binding to specific receptors [16]. In fact, Cry proteins that form oligomeric structures are related to a high pore activity [33]. Oligomerization of 3-domain Cry proteins has been described for toxins active against different insect orders, such as Cry3 proteins in coleopteran larvae. In the brush border membrane of L. decemlineata, Cry3A, Cry3B 
and Cry3C form an oligomer prior to membrane insertion, generating a pre-pore structure that can be inserted into the membrane [168]. Cry3Aa oligomeric structures have also been reported after incubation of Cry3Aa protoxin with T. molitor BBMV [127]. The oligomeric structure eventually leads to the lytic pore formation that disrupts the midgut insect cell by osmotic shock. However, oligomerization studies of Cry1 Ab and Cry1Ia proteins incubated with lepidopteran and coleopteran BBMV, as well as culture insect cells, showed that Cry1Ia oligomerization may not be a requirement for toxicity [179]. Besides, the appearance of Cry1Ab oligomers when incubated with coleopteran BBMV could be due to an improper insertion of oligomers into the membrane or the inability to induce the post-pore events in the cells [179]. Either way, susceptible insects can withstand minor damage, but greater damage destroys the epithelium of the midgut, leading to a disruption in feeding and subsequent starvation death. Additional to the toxin action, spores may pass through the channel, to colonize and germinate in the hemolymph and contribute to insect death by septicemia [1].

\section{The Secretable Coleopteran-Active Proteins}

In addition to the $\delta$-endotoxins produced during the stationary phase, other protein compounds have been found in the culture supernatant of certain entomopathogenic Bacillus isolates. These proteins, produced during the vegetative growth stage of the bacterium, were designated as vegetative insecticidal proteins (Vip) [180] and secreted insecticidal proteins (Sip) [181]. Within the Vip family, vip1 and vip2 genes are co-transcript in a single $4 \mathrm{kbp}$ operon, which render proteins of about $100 \mathrm{kDa}$ (Vip1) and $50 \mathrm{kDa}$ (Vip2) [171]. The absence of toxicity of the proteins alone suggests that it is a binary toxin for some members of the coleopteran [180] and hemipteran [182] orders. In contrast, Vip3 proteins are single-chain toxins with insecticidal activity against a wide range of lepidopteran species [183]. While B. thuringiensis is a good source of Vip proteins, these proteins have also been found in other closely related bacteria, such as Bacillus cereus, Lysinibacillus sphaericus, or Brevibacillus leterosporus. Currently, two Sip proteins have been described, both active against several coleopteran pests. The fact that strains harboring sip $1 A a$ and $\operatorname{sip} 1 A b$ genes also contain $c r y 3$ and cry 8 genes, respectively, suggests that Sip1 proteins may have a role in the insecticidal mechanism against coleopteran insects [184].

\subsection{Protein Structure}

Vip1 and Vip2 proteins are found in the culture supernatant before cell lysis due to specific secretion [181,185]. Both proteins have an $\mathrm{N}$-terminal signal peptide for secretion, commonly cleaved after the secretion process is completed [24,181]. The Vip1/Vip2 homology with other bacterial binary toxins and the fact that these proteins are codified by two genes encoded in a single operon, suggest the presence of a typical " $\mathrm{A}+\mathrm{B}$ " binary toxin $[24,185]$. It has been proposed that Vip1, with moderate sequence identity $(30 \%)$ and structural similarity with the binding C2-II Clostridium botulinum toxin and the toxin " $\mathrm{B}$ " of Clostridium difficile, is the binding domain that translocates Vip2, with homology to the Rho-ADP-ribosylatin exotoxin C3 of Clostridium spp, to the host cell $[186,187]$. As occurs with other related "B" compounds, Vip1 is formed by four domains involved in docking to enzymatic components, binding to specific cell surface receptors, oligomerization, and channel formation in lipid membranes [188]. Coleopteran active Sip1Aa protein contains a predicted Gram-positive consensus secretion signal [4] and exhibits 46\% similarity with Mtx3 mosquitocidal toxin of Lysinibacillus sphaericus [184]. This homology may indicate that Sip1Aa toxicity should be caused by pore formation.

\subsection{Insecticidal Activity}

The activity of the Bt secretable toxins against coleopterans is depicted in Table 2. Currently, four Vip protein families have been identified, but only Vip1/Vip2 showed activity against coleopteran pests [189]. Vip1/Vip2 proteins have been tested against different coleopteran families but they have shown active only against the Chrysomelidae, Curculionidae, and Scarabeidae families, being particularly toxic to corn rootworms. Single Vip1 or Vip2 showed no mortality, confirming that 
these proteins must act together to be toxic [185]. Vip1Aa was highly toxic against Diabrotica spp. when combined with Vip2Aa or Vip2Ab, but Vip1Ab/Vip2Ab (co-expressed in the same operon) and Vip1Ab/Vip2Aa were not active [185]. These data show the specificity of these proteins and suggest that the absence of toxicity is due to Vip1Ab. Moreover, Vip1Ba/Vip2Ba and Vip1Bb/Vip1Ba were toxic against Diabrotica virgifera virgifera [190] and binary Vip1Da/Vip1Ad had activity against the curculionid A. grandis and the chrysomelids Diabrotica spp and L. decemlineata [191]. These are the only Vip proteins active against the Colorado potato beetle. Vip1Ad/Vip2Ag binary proteins were the first report of demonstrated toxicity against any Scarabaeoidea larvae, being active against Holotrichia parallela, H. oblita and Anomala corpulenta [192]. Sip1Aa and Sip1Ab proteins have specific activity against coleopteran pests. Sip1Aa caused lethal toxicity for L. decemlineata larvae and stunting in D. virgifera and D. undecimpunctata larvae [181]. Sip1Ab was also toxic to Colaphellus bowringi Baly (Coleoptera: Chrysomelidae) but it did not harm Hloltrichia diomphalia (Coleoptera: Scarabaeidae) larvae [184], suggesting specific chrysomelid activity, although further studies are needed to determine its host range.

\subsection{Mode of Action}

The mode of action of coleopteran-specific Bt secretable proteins is poorly understood, but some information is available for this binary mechanism of action. The proposed multistep process begins with the ingestion of the two toxins by the susceptible larvae. Though the two encoded proteins are synthesized together, they are thought not to get associated in solution and reach the insect midgut as single proteins [188]. Then, the proteolytic processing by the trypsin-like proteases of the insect midgut juice of Vip1 allows the cell-bound " $\mathrm{B}$ " to bind to a specific membrane receptor, followed by the formation of oligomers containing seven Vip1 molecules [193]. It is at this stage when the docking between Vip1 and Vip2 translocates the toxic component (Vip2) into the cytoplasm though the "B" (Vip1) channel [188]. Recent studies in BBMVs of H. parallela evidenced that although Vip2Ag showed a low degree of binding on its own, the degree of binding increased when Vip1Ad was added, showing that Vip1Ad acted as a receptor to help Vip2 bind to BBMVs [194]. Once inside the cytosol, Vip2 destroys filamentous actin by blocking its polymerization and leading to cell death [195].

Sip1 proteins have no homology with Vip proteins, but Sip1A exhibits limited sequence similarity with the 36-kDa mosquitocidal Mtx3 protein of B. sphaericus, suggesting that toxicity is related with pore formation [181].

Table 2. Insecticidal activity of Vip and Sip proteins against coleopteran pests.

\begin{tabular}{|c|c|c|c|c|c|}
\hline \multirow{2}{*}{ Crystal Type Toxin } & \multicolumn{2}{|c|}{ Target Insect } & \multirow{2}{*}{ Activity $^{(a)}$} & \multirow{2}{*}{$\mathrm{LC}_{50}$} & \multirow{2}{*}{ Reference } \\
\hline & Scientific Name & Family & & & \\
\hline \multirow[t]{4}{*}{ Sip1Aa } & Diabrotica undecimpuntata & Chrysomelidae & A & & [181] \\
\hline & Diabrotica virgifera & Chrysomelidae & A & & [181] \\
\hline & Colaphellus bowringi & Chrysomelidae & A & 1.07 & [184] \\
\hline & Leptinotarsa decemlineata & Chrysomelidae & A & 24 & [181] \\
\hline \multirow[t]{2}{*}{ Sip1Ab } & Colaphellus bowringi & Chrysomelidae & A & 1.05 & [184] \\
\hline & Hloltrichia diomphalia & Scarabaeidae & $\mathrm{N}$ & & {$[184]$} \\
\hline Vip1Aa & Diabrotica virgifera & Chrysomelidae & $\mathrm{N}$ & & [185] \\
\hline \multirow[t]{2}{*}{ Vip1Ac } & Holotrichia oblita & Scarabaeidae & $\mathrm{N}$ & & [196] \\
\hline & Tenebrio molitor & Tenebrionidae & $\mathrm{N}$ & & [195] \\
\hline \multirow[t]{3}{*}{ Vip1ad } & Anomala corpulenta & Scarabaeidae & $\mathrm{N}$ & & [192] \\
\hline & Holotrichia oblita & Scarabaeidae & $\mathrm{N}$ & & [192] \\
\hline & Holotrichia parallela & Scarabaeidae & $\mathrm{N}$ & & [192] \\
\hline Vip1Da & Diabrotica virgifera & Chrysomelidae & $\mathrm{N}$ & & [191] \\
\hline Vip2Aa & Diabrotica virgifera & Chrysomelidae & $\mathrm{N}$ & & [185] \\
\hline Vip2Ac & Tenebrio molitor & Tenebrionidae & $\mathrm{N}$ & & [195] \\
\hline Vip2Ad & Diabrotica virgifera & Chrysomelidae & $\mathrm{N}$ & & [191] \\
\hline
\end{tabular}


Table 2. Cont.

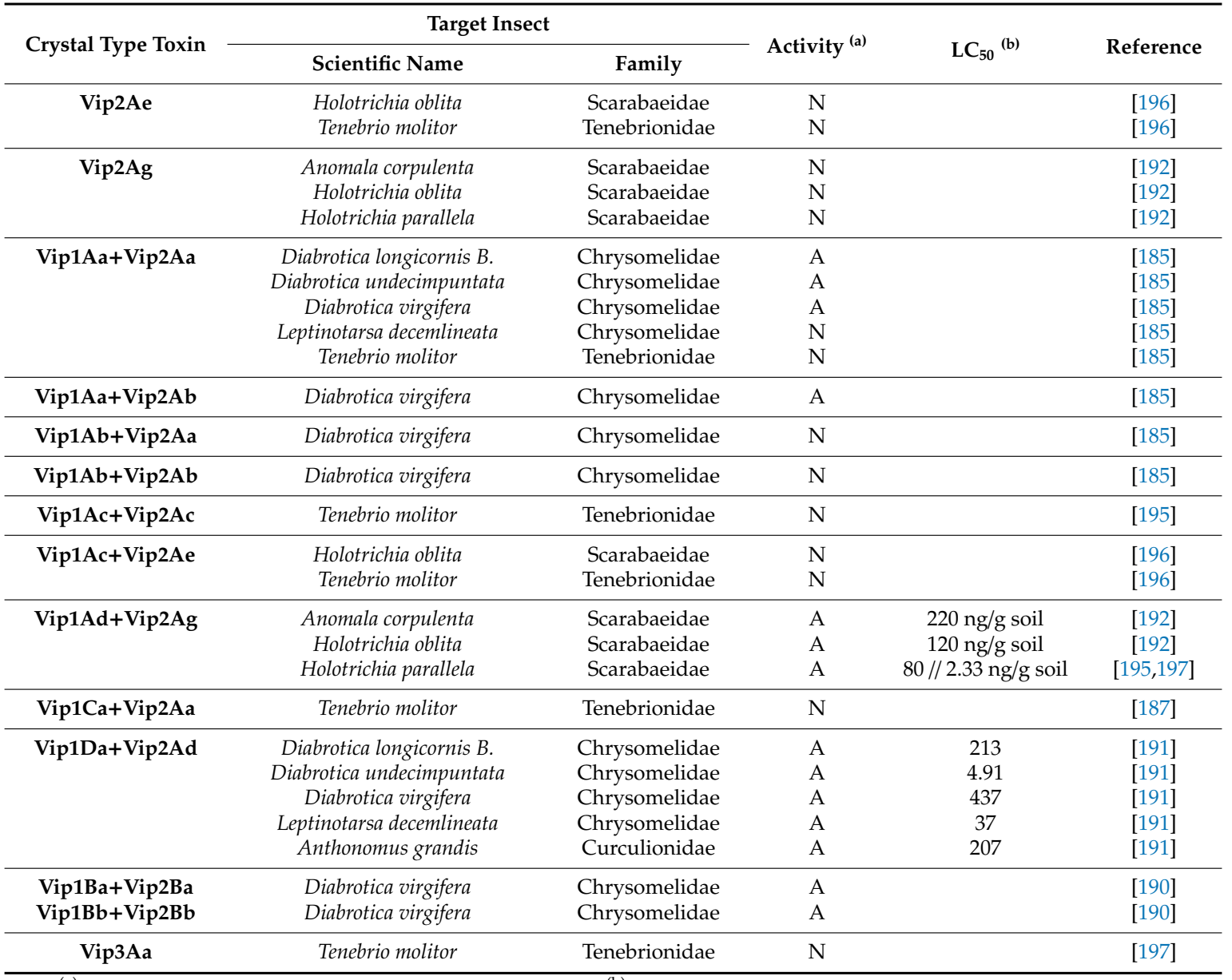

(a) The parameter is mortality. $\mathrm{A}=$ active; $\mathrm{N}=$ not active; ${ }^{(\mathrm{b})} \mathrm{LC}_{50}=$ lethal concentration that causes $50 \%$ mortality of the insects. data are expressed in $\mu \mathrm{g} / \mathrm{mL}$, unless otherwise stated. "//" separate two different values of the $\mathrm{LC}_{50}$.

\section{Bt Based Insecticides}

In 1938, the first insecticide based on B. thuringiensis was produced and marketed under the name Sporéine for the control of lepidopteran insect pests [47]. Since then, sporulated cultures of $B$. thuringiensis have been used widely as foliar sprays to protect crops from insect damage. Since $B$. thuringiensis subsp. tenebrionis was discovered [48], it was rapidly formulated as a bioinsecticide and commercialized against the Colorado potato beetle. Bt-based insecticides to control coleopteran pests are mainly developed against chrysomelid beetles [198]. Novodor ${ }^{\circledR}$ (Kenogard) uses the NB-176 strain of Bt subsp. tenebrionis as the active ingredient and is widely used for the control of L. decemlineata. However, the toxicity of this commercial product has been verified for other species of beetles, such as the chrysomelids Chrysophtharta bimaculata, C. agricola and C. scripta $[199,200]$ under laboratory conditions. Furthermore, this product has been shown to be effective against C. scripta in field conditions [200], while the use of Novodor did not exert good control of the populations of Lissorhoptrus oryzophilus (Coleoptera: Curculionidae) [201].

To date, most of the Bt-based bioinsecticide products effectively use natural Bt strains for the control of foliar-feeding pests. However, several factors have limited their use. Usually, Bt strains have a narrow insecticidal spectrum compared with other insecticides, even when insects are closely related [202]. Advances in genetic manipulation technologies offer improvements in the efficiency of Bt-based formulates and reductions in their production costs. The development of new strains by conjugation or transduction has been used to confer natural strains with new insecticidal properties [203]. The natural Bt subsp. kurstaki, for example, has been modified to express several cry3 genes and extend its host range 
to both lepidopteran and coleopteran pests [202]. The active ingredient in Foil ${ }^{\circledR}$ is the Bt strain EG2424, expressing both Cry1Ac and Cry3A proteins, the latter of which was transferred from a Cry3Aa-encoding plasmid belonging to the Bt subsp. morrisoni [204]. Similarly, the Cry3-overproducing strain, EG7673, was obtained by transforming a natural strain with a recombinant plasmid containing a cry3Bb1 gene. A formulation with this strain as the active ingredient was commercialized as Raven ${ }^{\circledR}$ and was four-fold more active than the parental strain [205].

\section{Bt-Crops}

By expressing one or more Bt toxic genes in a target plant tissue transgenic insect-resistant crops, Bt crops, can be produced. Such cultivars need no further pest control measures. To date, the Bt crops extension has increased worldwide, particularly that of Bt cotton, Bt rice and Bt corn [9]. Bt plants have been created for the control of several insect pests, among others, Colorado potato beetle (L. decemlineata) and corn rootworms (Diabrotica spp.). The first human-modified pesticide-producing crop was potato, which expressed the cry $3 A$ gene from $B$. thuringiensis subsp. tenebrionis in their leaves [206]. The transgenic gene expression confers potato plants protection against the Colorado potato beetle and allows reducing insecticide applications [207]. A few years later, this Bt crop was complemented with another gene expression cassette that also provided protection against the Potato leafroll virus [208]. However, genetically modified potatoes were commercialized from 1995 to 2001, and eventually removed from the marketplace due to social concern for genetically modified crops [209].

A coleopteran-active Bt maize was designed for the control of corn rootworms, expressing a variant of the wild-type cry3Bb1 gene from Bt subsp. kumamotoensis in the root tissue [210]. Currently, Bt maize hybrids express four different crystal proteins (Cry3Bb, mCry3A, Cry34Ab/35Ab and eCry3.1Ab), individually or co-expressing two toxins [211,212]. Vip1 and Vip2 proteins were also candidates to be expressed in maize plants, mainly due to the great toxicity against rootworms. However, the cytotoxic activity of the Vip2 protein has prevented the development of a Bt plant expressing this binary toxins [189]. The opportunity of expressing the toxin in a specific tissue allows minimization of the exposure of non-target fauna while increasing the control of tunneling and root pests, which are otherwise difficult to manage. However, Western corn rootworm has developed field resistance to all four currently available Bt toxins [212-214] as did D. virgifera in 2009 against Bt corn [55]. These facts show that although Bt crops have the potential to increase productivity while conserving biodiversity, resistance management programs and a better use of integrated pest management are necessary to delay resistance development as much as possible [215].

\section{Resistance and Cross-Resistance}

The widespread use of $B$. thuringiensis biopesticides, as well as the planting of millions of hectares of Bt plants to protect crops from pests, carry the risk of selecting insect biotypes that are tolerant or resistance to $\mathrm{Bt}$ toxins. The appearance of resistance may be due to alterations in any step involved their mode of action, from the solubilization and activation steps to the capacity of pore formation [159]. It is established that the lack of solubilization is favored by the physicochemical conditions of the midgut fluids, particularly the $\mathrm{pH}$. The acidic midgut of the coleopteran insects seemed to be a limiting factor in the solubilization of Cry proteins, such as Cry1B and Cry7Aa [52,71], although recent reports seem to indicate that more factors are involved as Cry7Aa proteins are dissolved in L. decemlineata and H. vigintioctomaculata midgut fluids $[57,58]$. Once the Cry toxin is solubilized in the midgut, protoxins are proteolytically cleaved to activated toxins. This toxin processing depends on the presence of the right digestive enzymes in the host midgut fluid. As an example, it was observed in D. virgifera larvae that the Cry3Aa protein was poorly processed by its own proteases, which leads to low activity of Cry3Aa against rootworms [157]. Introduction of a chymotrypsin/cathepsin recognition site in domain I of Cry3A has been shown to enhance the bioactivity of this toxin against the western corn rootworm larvae [157]. 
Molecularly, the insect resistance basis is a modification or loss of the specific midgut cell membrane receptors or some mediator, which eliminates or reduces the capacity of the toxin to initiate a lethal pathway [216]. Cross-resistance between Cry toxins is often associated with sequence similarities in domains II and III, related to specific protein binding [217]. Under laboratory conditions, populations of $L$. decemlineat $a$ and C. scripta resistant to Cry3Aa have been described $[53,54]$. To date, the appearance of field resistance is still relatively low despite the extensive use of products based on the same protein, which increases the probability of resistance development.

Conversely, rootworm populations have developed resistance to all proteins used in transgenic corn. The intense selection pressure posed by the continuous exposure of insects to Bt toxins has increased the emergence of pest resistance. Since the first case of resistance to Cry3Bb1 Bt-maize in 2009, Diabrotica has developed resistance to Cry3Aa and Cry34/35Ab binary protein [211]. New strategies are being carried out to try to delay resistance, including a combined use of several proteins in the same $\mathrm{Bt}$ plant [218]. Pyramiding of two Bt proteins can delay resistance to those proteins because when insects become tolerant to one toxin, most will still be susceptible to the other toxin [211]. However, there is already evidence of cross-resistance to Cry3 proteins and even to Cry34/35, which may invalidate, in the long run, the use of all these proteins [212].

Author Contributions: Conceptualization, M.D.-A., C.A.-A. and P.C.; resources, C.A.-A., B.E., and P.C.; writing-original draft, M.D.-A.; writing and editing, M.D.-A., M.V., B.E., and P.C.; review and supervision, M.V. and P.C. All authors have read and agreed to the published version of the manuscript.

Funding: This research was funded by the Spanish Ministry of Science and Innovation (RTI2018-095204-B-C22).

Acknowledgments: M.D.-A. received a doctoral grant from Universidad Pública de Navarra, Pamplona, Spain.

Conflicts of Interest: The authors declare no conflict of interest. The funders had no role in the design of the study; in the collection, analyses, or interpretation of data; in the writing of the manuscript, or in the decision to publish the results.

\section{References}

1. Raymond, B.; Johnston, P.R.; Nielsen-LeRoux, C.; Lereclus, D.; Crickmore, N. Bacillus thuringiensis: An impotent pathogen? Trends Microbiol. 2010, 18, 189-194. [CrossRef]

2. Schnepf, E.; Crickmore, N.; Van Rie, J.; Lereclus, D.; Baum, J.; Feitelson, J.; Zeigler, D.R.; Dean, D.H. Bacillus thuringiensis and its pesticidal crystal proteins. Microbiol. Mol. Biol. Rev. 1998, 62, 775-806. [CrossRef] [PubMed]

3. Wei, J.-Z.; Hale, K.; Carta, L.; Platzer, E.; Wong, C.; Fang, S.-C.; Aroian, R.V. Bacillus thuringiensis crystal proteins that target nematodes. Proc. Natl. Acad. Sci. USA 2003, 100, 2760-2765. [CrossRef] [PubMed]

4. Palma, L.; Muñoz, D.; Berry, C.; Murillo, J.; Caballero, P. Bacillus thuringiensis Toxins: An Overview of Their Biocidal Activity. Toxins 2014, 6, 3296-3325. [CrossRef] [PubMed]

5. Nester, E.W.; Thomashow, L.S.; Metz, M.; Gordon, M. 100 Years of Bacillus thuringiensis: A critical scientific assessment. Am. Soc. Microbiol. 2002.

6. Portela-Dussán, D.D.; Chaparro-Giralddo, A.; López-Pazos, S.A. La biotecnología de Bacillus thuringiensis en la agricultura. Nova 2013, 11, 87-96. [CrossRef]

7. Krishnan, V.; Domanska, B.; Elhigazi, A.; Afolabi, F.; West, M.J.; Crickmore, N. The human cancer cell active toxin Cry41Aa from Bacillus thuringiensis acts like its insecticidal counterparts. Biochem. J. 2017, 474, 1591-1602. [CrossRef]

8. Bravo, A.; Likitvivatanavong, S.; Gill, S.S.; Soberón, M. Bacillus thuringiensis: A story of a successful bioinsecticide. Insect Biochem. Mol. Biol. 2011, 41, 423-431. [CrossRef] [PubMed]

9. James, C. Global Status of Commercialized Biotech/GM Crops in 2017: Biotech Crop Adoption Surges as Economic Benefits Accumulate in 22 Years; ISAAA Br. No. 53; ISAAA: Ithaca, NY, USA, 2017.

10. Schnepf, H.E.; Whiteley, H.R. Cloning and expression of the Bacillus thuringiensis crystal protein gene in Escherichia coli. Proc. Natl. Acad. Sci. USA 1981, 78, 2893-2897. [CrossRef]

11. Crickmore, N.; Zeigler, D.R.; Feitelson, J.; Schnepf, E.; Van Rie, J.; Lereclus, D.; Baum, J.; Dean, D.H. Revision of the nomenclature for the Bacillus thuringiensis pesticidal crystal proteins. Microbiol. Mol. Biol. Rev. 1998, 62, 807-813. [CrossRef] 
12. Crickmore, N.; Baum, J.A.; Bravo, A.; Lereclus, D.; Narva, K.E.; Sampson, K.; Schnepf, H.E.; Sun, M.; Zeigler, D.R. Bacillus thuringiensis Toxin Nomenclature. Available online: http://www.btnomenclature.info/ (accessed on 30 May 2020).

13. Bravo, A.; Soberón, M.; Gill, S.S. Bacillus thuringiensis: Mechanisms and Use. In Insect Control: Biological and Synthetic Agents; Gilbert, L.I., Gill, S.S., Eds.; Elsevier: Amsterdam, The Netherlands, 2005; pp. 175-205.

14. Berry, C.; Crickmore, N. Structural classification of insecticidal proteins-Towards an in silico characterisation of novel toxins. J. Invertebr. Pathol. 2017, 142, 16-22. [CrossRef] [PubMed]

15. de Maagd, R.A.; Bravo, A.; Crickmore, N. How Bacillus thuringiensis has evolved specific toxins to colonize the insect world. Trends Genet. 2001, 17, 193-199. [CrossRef]

16. Pardo-López, L.; Soberón, M.; Bravo, A. Bacillus thuringiensis insecticidal three-domain Cry toxins: Mode of action, insect resistance and consequences for crop protection. FEMS Microbiol. Rev. 2013, 37, 3-22. [CrossRef] [PubMed]

17. Oppert, B.; Ellis, R.T.; Babcock, J. Effects of Cry1F and Cry34Ab1/35Ab1 on storage pests. J. Stored Prod. Res. 2010, 46, 143-148. [CrossRef]

18. Yu, Y.; Yuan, Y.; Gao, M. Construction of an environmental safe Bacillus thuringiensis engineered strain against Coleoptera. Appl. Microbiol. Biotechnol. 2016, 100, 4027-4034. [CrossRef]

19. Jolivet, P. Food Habits and Food Selection of Chrysomelidae. Bionomic and Evolutionary Perspectives. In Biology of Chrysomelidae; Jolivet, P., Petitpierre, E., Hsiao, T.H., Eds.; Springer: Dordrecht, The Netherlands, 1988; pp. 1-24.

20. Soberón, M.; López-Díaz, J.A.; Bravo, A. Cyt toxins produced by Bacillus thuringiensis: A protein fold conserved in several pathogenic microorganisms. Peptides 2013, 41, 87-93. [CrossRef]

21. Bietlot, H.P.; Vishnubhatla, I.; Carey, P.R.; Pozsgay, M.; Kaplan, H. Characterization of the cysteine residues and disulphide linkages in the protein crystal of Bacillus thuringiensis. Biochem. J. 1990, 267, 309-315. [CrossRef]

22. Agaisse, H.; Lereclus, D. How does Bacillus thuringiensis produce so much insecticidal crystal protein? J. Bacteriol. 1995, 177, 6027-6032. [CrossRef]

23. Berry, C.; Ben-dov, E.; Jones, A.F.; Murphy, L.; Quail, M.A.; Holden, M.T.G.; Harris, D.; Zaritsky, A.; Parkhill, J. Complete sequence and organization of pBtoxis, the Toxin-Coding Plasmid of Bacillus thuringiensis subsp. israelensis. Appl. Environ. Microbiol. 2002, 68, 5082-5095. [CrossRef]

24. de Maagd, R.A.; Bravo, A.; Berry, C.; Crickmore, N.; Schnepf, H.E. Structure, diversity, and evolution of protein toxins from spore-forming entomopathogenic bacteria. Annu. Rev. Genet. 2003, 37, 409-433. [CrossRef]

25. Li, J.D.; Carroll, J.; Ellar, D.J. Crystal structure of insecticidal d-endotoxin from Bacillus thuringiensis at 2.5 A resolution. Nature 1991, 353, 815-821. [CrossRef] [PubMed]

26. Grochulski, P.; Masson, L.; Borisova, S.; Pusztai-Carey, M.; Schwartz, J.-L.; Brousseau, R.; Cygler, M. Bacillus thuringiensis CrylA(a) Insecticidal Toxin: Crystal structure and channel formation. J. Mol. Biol. 1995, 254, 447-464. [CrossRef] [PubMed]

27. Morse, R.J.; Yamamoto, T.; Stroud, R.M. Structure of Cry2Aa Suggests an Unexpected Receptor Binding Epitope. Structure 2001, 9, 409-417. [CrossRef]

28. Galitsky, N.; Cody, V.; Wojtczak, A.; Ghosh, D.; Luft, J.R.; Pangborn, W.; English, L. Structure of the insecticidal bacterial $\delta$-endotoxin Cry3Bb1 of Bacillus thuringiensis. Acta Crystallogr. Sect. D Biol. Crystallogr. 2001, 57, 1101-1109. [CrossRef] [PubMed]

29. Boonserm, P.; Davis, P.; Ellar, D.J.; Li, J. Crystal structure of the mosquito-larvicidal toxin Cry4Ba and its biological implications. J. Mol. Biol. 2005, 348, 363-382. [CrossRef] [PubMed]

30. Boonserm, P.; Mo, M.; Angsuthanasombat, C.; Lescar, J. Structure of the functional form of the mosquito larvicidal Cry4Aa toxin from Bacillus thuringiensis at 2.8-Angstrom resolution. J. Bacteriol. 2006, 188, 3391-3401. [CrossRef]

31. Guo, S.; Ye, S.; Liu, Y.; Wei, L.; Xue, J.; Wu, H.; Song, F.; Zhang, J.; Wu, X.; Huang, D.; et al. Crystal structure of Bacillus thuringiensis Cry8Ea1: An insecticidal toxin toxic to underground pests, the larvae of Holotrichia parallela. J. Struct. Biol. 2009, 168, 259-266. [CrossRef]

32. Ye, Y.; Godzik, A. FATCAT: A web server for flexible structure comparison and structure similarity searching. Nucleic Acids Res. 2004, 32, W582-W585. [CrossRef] 
33. Bravo, A.; Gill, S.S.; Soberón, M. Mode of action of Bacillus thuringiensis Cry and Cyt toxins and their potential for insect control. Toxicon 2007, 49, 423-435. [CrossRef]

34. Xu, C.; Wang, B.-C.; Yu, Z.; Sun, M. Structural Insights into Bacillus thuringiensis Cry, Cyt and Parasporin Toxins. Toxins 2014, 6, 2732-2770. [CrossRef]

35. Yamaguchi, T.; Sahara, K.; Bando, H.; Asano, S. Discovery of a novel Bacillus thuringiensis Cry8D protein and the unique toxicity of the Cry8D-class proteins against scarab beetles. J. Invertebr. Pathol. 2008, 99, 257-262. [CrossRef] [PubMed]

36. Bokori-Brown, M.; Savva, C.G.; Fernandes Da Costa, S.P.; Naylor, C.E.; Basak, A.K.; Titball, R.W. Molecular basis of toxicity of Clostridium perfringens epsilon toxin. FEBS J. 2011, 278, 4589-4601. [CrossRef] [PubMed]

37. Donovan, W.P.; Donovan, J.C.; Slaney, A.C. Bacillus thuringiensis CryET33 and CryET34 Compositions and Uses Therefor. U.S. Patent 6,063,756 A, 16 May 2000.

38. Rydel, T.; Sharamitaro, J.; Brown, G.R.; Gouzov, V.; Seale, J.; Sturman, E.; Thoma, R.; Gruys, K.; Isaac, B. The crystal structure of a coleopteran insect-active binary Bt protein toxin complex at $2.5 \AA$ resolution. In Proceedings of the Annual Meeting of the American Crystallographic Association, Los Angeles, CA, USA, 21-26 July 2001.

39. Baum, J.A.; Chu, C.R.; Rupar, M.; Brown, G.R.; Donovan, W.P.; Huesing, J.E.; Ilagan, O.; Malvar, T.M.; Pleau, M.; Walters, M.; et al. Binary toxins from Bacillus thuringiensis active against the western corn rootworm, Diabrotica virgifera virgifera LeConte. Appl. Environ. Microbiol. 2004, 70, 4889-4898. [CrossRef]

40. Ellis, R.T.; Stockhoff, B.A.; Stamp, L.; Schnepf, H.E.; Schwab, G.E.; Knuth, M.; Russell, J.; Cardineau, G.A.; Narva, K.E. Novel Bacillus thuringiensis binary insecticidal Crystal proteins active on Western Corn Rootworm, Diabrotica virgifera virgifera LeConte. Appl. Environ. Microbiol. 2002, 68, 1137-1145. [CrossRef]

41. Kelker, M.S.; Berry, C.; Evans, S.L.; Pai, R.; McCaskill, D.G.; Wang, N.X.; Russell, J.C.; Baker, M.D.; Yang, C.; Pflugrath, J.W.; et al. Structural and Biophysical Characterization of Bacillus thuringiensis Insecticidal Proteins Cry34Ab1 and Cry35Ab1. PLoS ONE 2014, 9, e112555. [CrossRef]

42. Cohen, S.; Albeck, S.; Ben-Dov, E.; Cahan, R.; Firer, M.; Zaritsky, A.; Dym, O. Cyt1Aa Toxin: Crystal structure reveals implications for Its membrane-perforating function. J. Mol. Biol. 2011, 413, 804-814. [CrossRef] [PubMed]

43. Li, J.; Koni, P.A.; Ellar, D.J. Structure of the mosquitocidal $\delta$-endotoxin CytB from Bacillus thuringiensis sp. kyushuensisand implications for membrane pore formation. J. Mol. Biol. 1996, 257, 129-152.

44. Cohen, S.; Dym, O.; Albeck, S.; Ben-Dov, E.; Cahan, R.; Firer, M.; Zaritsky, A. High-Resolution crystal structure of activated Cyt2Ba monomer from Bacillus thuringiensis subsp. israelensis. J. Mol. Biol. 2008, 380, 820-827. [CrossRef]

45. Gazit, E.; Burshtein, N.; Ellar, D.J.; Sawyer, T.; Shai, Y. Bacillus thuringiensis Cytolytic toxin associates specifically with Its synthetic Helices A and C in the membrane Bound State. Implications for the assembly of oligomeric transmembrane pores. Biochemistry 1997, 36, 15546-15554. [CrossRef]

46. Promdonkoy, B.; Rungrod, A.; Promdonkoy, P.; Pathaichindachote, W.; Krittanai, C.; Panyim, S. Amino acid substitutions in $\alpha \mathrm{A}$ and $\alpha \mathrm{C}$ of Cyt2Aa2 alter hemolytic activity and mosquito-larvicidal specificity. J. Biotechnol. 2008, 133, 287-293. [CrossRef]

47. Federici, B.A.; Park, H.-W.; Sakano, Y. Insecticidal Protein Crystals of Bacillus thuringiensis. In Inclusions in Prokaryotes; Springer: Berlin/Heidelberg, Germany, 2006; pp. 195-236.

48. Krieg, A.; Huger, A.M.; Langenbruch, G.A.; Schnetter, W. Bacillus thuringiensis var. tenebrionis: Ein neuer, gegenüber Larven von Coleopteren wirksamer Pathotyp. Zeitschrift für Angew. Entomol. 2009, 96, 500-508.

49. Herrnstadt, C.; Soares, G.G.; Wilcox, E.R.; Edwards, D.L. A new strain of Bacillus thuringiensis with activity against coleopteran insects. Nat. Biotechnol. 1986, 4, 305-308.

50. Barjac, H.; Frachon, E. Classification of Bacillus thuringiensis strains. Entomophaga 1990, 35, 233-240. [CrossRef]

51. Rupar, M.J.; Donovan, W.P.; Groat, R.G.; Slaney, A.C.; Mattison, J.W.; Johnson, T.B.; Charles, J.F.; Dumanoir, V.C.; de Barjac, H. Two novel strains of Bacillus thuringiensis toxic to coleopterans. Appl. Environ. Microbiol. 1991, 57, 3337-3344. [CrossRef] [PubMed]

52. Lambert, B.; Höfte, H.; Annys, K.; Jansens, S.; Soetaert, P.; Peferoen, M. Novel Bacillus thuringiensis insecticidal crystal protein with a silent activity against coleopteran larvae. Appl. Environ. Microbiol. 1992, 58, 2536-2542.

53. Whalon, M.E.; Miller, D.L.; Hollingworth, R.M.; Grafius, E.J.; Miller, J.R. Selection of a Colorado Potato Beetle (Coleoptera: Chrysomelidae) Strain Resistant to Bacillus thuringiensis. J. Econ. Entomol. 1993, 86, $226-233$. [CrossRef] 
54. Bauer, L.S. Resistance: A threat to the insecticidal crystal proteins of Bacillus thuringiensis. Florida Entomol. 1995, 78, 414-443. [CrossRef]

55. Gassmann, A.J.; Petzold-Maxwell, J.L.; Keweshan, R.S.; Dunbar, M.W. Field-Evolved Resistance to Bt Maize by Western Corn Rootworm. PLoS ONE 2011, 6, e22629. [CrossRef]

56. Ekobu, M.; Solera, M.; Kyamanywa, S.; Mwanga, R.O.M.; Odongo, B.; Ghislain, M.; Moar, W.J. Toxicity of seven Bacillus thuringiensis Cry proteins against Cylas puncticollis and Cylas brunneus (Coleoptera: Brentidae) using a novel artificial diet. J. Econ. Entomol. 2010, 103, 1493-1502. [CrossRef]

57. Domínguez-Arrizabalaga, M.; Villanueva, M.; Fernandez, A.B.; Caballero, P. A strain of Bacillus thuringiensis containing a novel cry7Aa2 gene that Is toxic to Leptinotarsa decemlineata (Say) (Coleoptera: Chrysomelidae). Insects 2019, 10, 259. [CrossRef]

58. Song, P.; Wang, Q.; Nangong, Z.; Su, J.; Ge, D. Identification of Henosepilachna vigintioctomaculata (Coleoptera: Coccinellidae) midgut putative receptor for Bacillus thuringiensis insecticidal Cry7Ab3 toxin. J. Invertebr. Pathol. 2012, 109, 318-322. [CrossRef]

59. Shu, C.; Yu, H.; Wang, R.; Fen, S.; Su, X.; Huang, D.; Zhang, J.; Song, F. Characterization of Two Novel cry8 genes from Bacillus thuringiensis Strain BT185. Curr. Microbiol. 2009, 58, 389-392. [CrossRef]

60. Shu, C.; Yan, G.; Wang, R.; Zhang, J.; Feng, S.; Huang, D.; Song, F. Characterization of a novel cry8 gene specific to Melolonthidae pests: Holotrichia oblita and Holotrichia parallela. Appl. Microbiol. Biotechnol. 2009, 84, 701-707. [CrossRef] [PubMed]

61. Gindin, G.; Mendel, Z.; Levitin, B.; Kumar, P.; Levi, T.; Shahi, P.; Khasdan, V.; Weinthal, D.; Kuznetsova, T.; Einav, M.; et al. The basis for rootstock resilient to Capnodis species: Screening for genes encoding $\delta$-endotoxins from Bacillus thuringiensis. Pest Manag. Sci. 2014, 70, 1283-1290. [CrossRef] [PubMed]

62. Park, Y.; Hua, G.; Taylor, M.D.; Adang, M.J. A coleopteran cadherin fragment synergizes toxicity of Bacillus thuringiensis toxins Cry3Aa, Cry3Bb, and Cry8Ca against lesser mealworm, Alphitobius diaperinus (Coleoptera: Tenebrionidae). J. Invertebr. Pathol. 2014, 123, 1-5. [PubMed]

63. Oliveira, G.R.; Silva, M.C.; Lucena, W.A.; Nakasu, E.Y.; Firmino, A.A.; Beneventi, M.A.; Souza, D.S.; Gomes, J.E.; de Souza, J.D.; Rigden, D.J.; et al. Improving Cry8Ka toxin activity towards the cotton boll weevil (Anthonomus grandis). BMC Biotechnol. 2011, 11, 85. [CrossRef] [PubMed]

64. Yu, H.; Zhang, J.; Huang, D.; Gao, J.; Song, F. Characterization of Bacillus thuringiensis strain Bt185 toxic to the Asian Cockchafer: Holotrichia parallela. Curr. Microbiol. 2006, 53, 13-17. [CrossRef] [PubMed]

65. Li, H.; Liu, R.; Shu, C.; Zhang, Q.; Zhao, S.; Shao, G.; Zhang, X.; Gao, J. Characterization of one novel cry8 gene from Bacillus thuringiensis strain Q52-7. World J. Microbiol. Biotechnol. 2014, 30, 3075-3080. [CrossRef] [PubMed]

66. Thomson, M.; Knuth, M.; Cardineau, G. Bacillus thuringiensis Toxins with Improved Activity. U.S. Patent 5,874,288 A, 23 February 1999.

67. Shrestha, G.; Reddy, G.V.P.; Jaronski, S.T. Field efficacy of Bacillus thuringiensis galleriae strain SDS-502 for the management of alfalfa weevil and its impact on Bathyplectes spp. parasitization rate. J. Invertebr. Pathol. 2018, 153, 6-11. [CrossRef]

68. Isaac, B.; Krieger, E.K.; Mettus, A.-M.L.; Moshiri, F.; Sivasupramanian, S. Polypeptide Compositions Toxic to Anthonomus Insects and Methods of Use. U.S. Patent 6,541,448 B2, 1 August 2002.

69. Mettus, A.-M.L.; Baum, J.A. Polypeptide Compositions Toxic to Diabrotica Insects, Obteined from Bt; CryET70, and Methods of Use. Eur. Patent Application EP 1129198 B1, 11 May 2000. 29 September 1999.

70. van Frankenhuyzen, K. Cross-order and cross-phylum activity of Bacillus thuringiensis pesticidal proteins. J. Invertebr. Pathol. 2013, 114, 76-85. [CrossRef]

71. Bradley, D.; Harkey, M.A.; Kim, M.K.; Biever, K.D.; Bauer, L. The insecticidal CryIB Crystal protein of Bacillus thuringiensis ssp. thuringiensis has dual specificity to Coleopteran and Lepidopteran larvae. J. Invertebr. Pathol. 1995, 65, 162-173. [CrossRef]

72. Federici, B.A.; Bauer, L.S. Cyt1Aa protein of Bacillus thuringiensis Is toxic to the Cottonwood Leaf Beetle, Chrysomela scripta, and suppresses high levels of resistance to Cry3Aa. Appl. Environ. Microbiol. 1998, 64, 4368-4371. [CrossRef] [PubMed]

73. Naimov, S.; Weemen-Hendriks, M.; Dukiandjiev, S.; de Maagd, R. Bacillus thuringiensis Delta-Endotoxin Cry1 Hybrid Proteins with Increased Activity against the Colorado Potato Beetle. Appl. Environ. Microbiol. 2001, 67, 5328-5330. [CrossRef] [PubMed] 
74. Martins, É.S.; Monnerat, R.G.; Queiroz, P.R.; Dumas, V.F.; Braz, S.V.; de Souza Aguiar, R.W.; Gomes, A.C.M.M.; Sánchez, J.; Bravo, A.; Ribeiro, B.M. Midgut GPI-anchored proteins with alkaline phosphatase activity from the cotton boll weevil (Anthonomus grandis) are putative receptors for the Cry1B protein of Bacillus thuringiensis. Insect Biochem. Mol. Biol. 2010, 40, 138-145. [CrossRef] [PubMed]

75. Rodríguez-González, Á.; Porteous-Álvarez, A.J.; Del Val, M.; Casquero, P.A.; Escriche, B. Toxicity of five Cry proteins against the insect pest Acanthoscelides obtectus (Coleoptera: Chrisomelidae: Bruchinae). J. Invertebr. Pathol. 2020, 169. [CrossRef] [PubMed]

76. Martins, É.S.; Praça, L.B.; Dumas, V.F.; Silva-Werneck, J.O.; Sone, E.H.; Waga, I.C.; Berry, C.; Monnerat, R.G. Characterization of Bacillus thuringiensis isolates toxic to cotton boll weevil (Anthonomus grandis). Biol. Control 2007, 40, 65-68. [CrossRef]

77. Asano, S. Identification of cry gene from Bacillus thuringiensis by PCR and isolation of unique insecticidal bacteria. Mem. Fac. Agric. 1996, 19, 529-563.

78. de Souza Aguiar, R.W.; Martins, É.S.; Ribeiro, B.M.; Monnerat, R.G. Cry10Aa Protein is highly toxic to Anthonomus grandis Boheman (Coleoptera: Curculionidae), an important insect pest in brazilian cotton crop fields. Bt Res. 2012, 3, 20-28.

79. Baum, J.A.; Sukuru, U.R.; Penn, S.R.; Meyer, S.E.; Subbarao, S.; Shi, X.; Flasinski, S.; Heck, G.R.; Brown, R.S.; Clark, T.L. Cotton Plants Expressing a Hemipteran-Active Bacillus thuringiensis Crystal Protein Impact the Development and Survival of Lygus hesperus (Hemiptera: Miridae) Nymphs. J. Econ. Entomol. 2012, 105, 616-624. [CrossRef]

80. Bradfisch, G.A.; Muller-Cohn, J.; Narva, K.E.; Fu, J.; Thomson, M. Bacillus thuringiensis toxins and Genes for Controlling Coleopteran Pests. U.S. Patent 6,710,027 B2, 23 March 2004.

81. Schnepf, H.E.; Lee, S.; Dojillo, J.; Burmeister, P.; Fencil, K.; Morera, L.; Nygaard, L.; Narva, K.E.; Wolt, J.D. Characterization of Cry34/Cry35 Binary Insecticidal Proteins from Diverse Bacillus thuringiensis Strain Collections. Appl. Environ. Microbiol. 2005, 71, 1765-1774. [CrossRef]

82. Moellenbeck, D.J.; Peters, M.L.; Bing, J.W.; Rouse, J.R.; Higgins, L.S.; Sims, L.; Nevshemal, T.; Marshall, L.; Ellis, R.T.; Bystrak, P.G.; et al. Insecticidal proteins from Bacillus thuringiensis protect corn from corn rootworms. Nat. Biotechnol. 2001, 19, 668-672. [CrossRef] [PubMed]

83. Rupar, M.J.; Donovan, W.P.; Tan, Y.; Slaney, A.C. Bacillus thuringiensis CryET29 Compositions Toxic to Coleopteran Insects and Ctenocephalides spp. U.S. Patent 6,093,695, 25 July 2000.

84. Weathersbee, A.A.; Lapointe, S.L.; Shatters, R.G. Activity of Bacillus thuringiensis isolates against Diaprepes abbreviatus (Coleoptera: Curculionidae). Florida Entomol. 2006, 89, 441-448. [CrossRef]

85. Mahmoud, S.B.; Ramos, J.E.; Shatters, R.G.; Hall, D.G.; Lapointe, S.L.; Niedz, R.P.; Rougé, P.; Cave, R.D.; Borovsky, D. Expression of Bacillus thuringiensis cytolytic toxin (Cyt2Ca1) in citrus roots to control Diaprepes abbreviatus larvae. Pesticide Biochem. Physiol. 2017, 136, 1-11. [CrossRef] [PubMed]

86. D'Amico, V.; Podgwaite, J.D.; Duke, S. Biological activity of Bacillus thuringiensis and associated toxins against the Asian Longhorned Beetle (Coleoptera: Cerambycidae). J. Entomol. Sci. 2004, 39, 318-324. [CrossRef]

87. Chen, J.; Dai, L.-Y.; Wang, X.-P.; Tian, Y.-C.; Lu, M.-Z. The cry3Aa gene of Bacillus thuringiensis Bt886 encodes a toxin against long-horned beetles. Appl. Microbiol. Biotechnol. 2005, 67, 351-356. [CrossRef] [PubMed]

88. Peña, G.; Miranda-Rios, J.; de la Riva, G.; Pardo-López, L.; Soberón, M.; Bravo, A. A Bacillus thuringiensis S-Layer Protein Involved in Toxicity against Epilachna varivestis (Coleoptera: Coccinellidae). Appl. Environ. Microbiol. 2006, 127, 353-360. [CrossRef]

89. Elgizawy, K.K.; Ashry, N.M. Efficiency of Bacillus thuringiensis strains and their Cry proteins against the Red Flour Beetle, Tribolium castaneum (Herbst.) (Coleoptera: Tenebrionidae). Egypt. J. Biol. Pest Control 2019, $29,94$. [CrossRef]

90. MacIntosh, S.C.; Stone, T.B.; Sims, S.R.; Hunst, P.L.; Greenplate, J.T.; Marrone, P.G.; Perlak, F.J.; Fischhoff, D.A.; Fuchs, R.L. Specificity and efficacy of purified Bacillus thuringiensis proteins against agronomically important insects. J. Invertebr. Pathol. 1990, 56, 258-266. [CrossRef]

91. Porcar, M.; García-Robles, I.; Domínguez-Escribà, L.; Latorre, A. Effects of Bacillus thuringiensis Cry1Ab and Cry3Aa endotoxins on predatory Coleoptera tested through artificial diet-incorporation bioassays. Bull. Entomol. Res. 2010, 100, 297-302. [CrossRef]

92. Chang, X.; Lu, Z.; Shen, Z.; Peng, Y.; Ye, G. Bitrophic and Tritrophic Effects of Transgenic cry $1 A b / c r y 2 A j$ Maize on the Beneficial, Nontarget Harmonia axyridis (Coleoptera: Coccinellidae). Environ. Entomol. 2017, 46, 1171-1176. [CrossRef] 
93. Sims, S.R. Host activity spectrum of the CryIIA Bacillus thuringiensis subsp. kurstaki protein. Effects on Lepidoptera, Diptera, and non-target arthropods. Southwest. Entomol. 1997, 22, 395-404.

94. Sharma, A.; Kumar, S.; Bhatnagar, R.K. Bacillus thuringiensis Protein Cry6B (BGSC ID 4D8) is Toxic to Larvae of Hypera postica. Curr. Microbiol. 2011, 62, 597-605. [CrossRef]

95. Niu, L.; Tian, Z.; Liu, H.; Zhou, H.; Ma, W.; Lei, C.; Chen, L. Transgenic Bt cotton expressing Cry1Ac/Cry2Ab or Cry1Ac/EPSPS does not affect the plant bug Adelphocoris suturalis or the pollinating beetle Haptoncus luteolus. Environ. Pollut. 2018, 234, 788-793. [CrossRef] [PubMed]

96. Contreras, E.; Rausell, C.; Real, M.D. Proteome response of Tribolium castaneum larvae to Bacillus thuringiensis toxin producing strains. PLoS ONE 2013, 8, e55330. [CrossRef]

97. Zhao, Y.; Zhang, S.; Luo, J.-Y.; Wang, C.-Y.; Lv, L.-M.; Wang, X.-P.; Cui, J.-J.; Lei, C.-L. Bt proteins Cry1Ah and Cry2Ab do not affect cotton aphid Aphis gossypii and ladybeetle Propylea japonica. Sci. Rep. 2016, 6, 20368. [CrossRef] [PubMed]

98. Zhong, C.; Ellar, D.J.; Bishop, A.; Johnson, C.; Lin, S.; Hart, E.R. Characterization of a Bacillus thuringiensis $\delta$-Endotoxin which ia toxic to insects in three orders. J. Invertebr. Pathol. 2000, 76, 131-139. [CrossRef] [PubMed]

99. Gómez, J.E.C.; López-Pazos, S.A.; Cerón, J. Determination of Cry toxin activity and identification of an aminopeptidase $\mathrm{N}$ receptor-like gene in Asymmathetes vulcanorum (Coleoptera: Curculionidae). J. Invertebr. Pathol. 2012, 111, 94-98. [CrossRef] [PubMed]

100. López-Pazos, S.A.; Rojas Arias, A.C.; Ospina, S.A.; Cerón, J. Activity of Bacillus thuringiensis hybrid protein against a lepidopteran and a coleopteran pest. FEMS Microbiol. Lett. 2010, 302, 93-98. [CrossRef] [PubMed]

101. Shin, B.S.; Park, S.H.; Choi, S.K.; Koo, B.T.; Lee, S.T.; Kim, J.I. Distribution of cryV-type insecticidal protein genes in Bacillus thuringiensis and cloning of cryV-type genes from Bacillus thuringiensis subsp. kurstaki and Bacillus thuringiensis subsp. entomocidus. Appl. Environ. Microbiol. 1995, 61, 2402-2407. [CrossRef] [PubMed]

102. Choi, S.-K.; Shin, B.-S.; Kong, E.-M.; Rho, H.M.; Park, S.-H. Cloning of a new Bacillus thuringiensis cry1I -Type crystal protein gene. Curr. Microbiol. 2000, 41, 65-69. [CrossRef]

103. Kostichka, K.; Warren, G.W.; Mullins, M.; Mullins, A.D.; Palekar, N.V.; Craig, J.A.; Koziel, M.G.; Estruch, J.J. Cloning of a cry $V$-type insecticidal protein gene from Bacillus thuringiensis: The cryV-encoded protein is expressed early in stationary phase. J. Bacteriol. 1996, 178, 2141-2144. [CrossRef] [PubMed]

104. Ruiz de Escudero, I.; Estela, A.; Porcar, M.; Martínez, C.; Oguiza, J.A.; Escriche, B.; Ferrè, J.; Caballero, P. Molecular and Insecticidal Characterization of a Cry1I Protein Toxic to Insects of the Families Noctuidae, Tortricidae, Plutellidae, and Chrysomelidae. Appl. Environ. Microbiol. 2006, 72, 4796-4804. [CrossRef] [PubMed]

105. Grossi-De-Sa, M.F.; De Magalhaes, M.Q.; Silva, M.S.; Silva, S.M.B.; Dias, S.C.; Nakasu, E.Y.T.; Brunetta, P.S.F.; Oliveira, G.R.; De Oliveira Neto, O.B.; De Oliveira, R.S.; et al. Susceptibility of Anthonomus grandis (Cotton Boll Weevil) and Spodoptera frugiperda (Fall Armyworm) to a Cry1Ia-type toxin from a Brazilian Bacillus thuringiensis strain. BMB Rep. 2007, 40, 773-782. [CrossRef] [PubMed]

106. Gleave, A.P.; Williams, R.; Hedges, R.J. Screening by polymerase chain reaction of Bacillus thuringiensis serotypes for the presence of $c r y V$-like insecticidal protein genes and characterization of a cry $V$ gene cloned from B. thuringiensis subsp. kurstaki. Appl. Environ. Microbiol. 1993, 59, 1683-1687. [CrossRef]

107. Mushtaq, R.; Behle, R.; Liu, R.; Niu, L.; Song, P.; Shakoori, A.R.; Jurat-Fuentes, J.L. Activity of Bacillus thuringiensis Cry1Ie2, Cry2Ac7, Vip3Aa11 and Cry7Ab3 proteins against Anticarsia gemmatalis, Chrysodeixis includens and Ceratoma trifurcata. J. Invertebr. Pathol. 2017, 150, 70-72. [CrossRef]

108. Liu, J.; Song, F.; Zhang, J.; Liu, R.; He, K.; Tan, J.; Huang, D. Identification of vip3A-type genes from Bacillus thuringiensis strains and characterization of a novel vip3A-type gene. Lett. Appl. Microbiol. 2007, 45, 432-438. [CrossRef]

109. von Tersch, M.A.; Gonzalez, J.M. Bacillus thuringiensis cryET1 Toxin Gene and Protein Toxic to Lepidopteran Insects. U.S. Patent 5,356,623 A, 18 October 1994.

110. Oppert, B.; Morgan, T.D.; Kramer, K.J. Efficacy of Bacillus thuringiensis Cry3Aa protoxin and protease inhibitors against coleopteran storage pests. Pest Manag. Sci. 2011, 67, 568-573. [CrossRef]

111. Zhongkamg, W.; He, W.; Peng, G.; Xia, Y. Transformation and expression of specific insecticide gene Bt cry3A in resident endogenetic bacteria isolated from Apriona germari (Hope) larvae intestines. Acta Microbiol. Sin. 2008, 48, 1168-1174. 
112. Kurt, A.; Özkan, M.; Sezen, K.; Demirbağ, Z.; Özcengiz, G. Cry3Aa11: A new Cry3Aa $\delta$-endotoxin from a local isolate of Bacillus thuringiensis. Biotechnol. Lett. 2005, 27, 1117-1121. [CrossRef]

113. Su, Z.; Deng, L.; Yi, X.; Xiao, S.; Zhang, C. The toxicity of Cry3Aa protein in Brontispa longissima by prokaryatic expression. Genomics Appl. Biol. 2009, 28, 691-694.

114. Génissel, A.; Leplé, J.C.; Millet, N.; Augustin, S.; Jouanin, L.; Pilate, G. High tolerance against Chrysomela tremulae of transgenic poplar plants expressing a synthetic cry $3 A a$ gene from Bacillus thuringiensis ssp. tenebrionis. Mol. Breed. 2003, 11, 103-110. [CrossRef]

115. James, R.R.; Croft, B.A.; Strauss, S.H. Susceptibility of the Cottonwood Leaf Beetle (Coleoptera: Chrysomelidae) to Different Strains and Transgenic Toxins of Bacillus thuringiensis. Environ. Entomol. 1999, 28, 108-115. [CrossRef]

116. Yan, G.; Song, F.; Shu, C.; Liu, J.; Liu, C.; Huang, D.; Feng, S.; Zhang, J. An engineered Bacillus thuringiensis strain with insecticidal activity against Scarabaeidae (Anomala corpulenta) and Chrysomelidae (Leptinotarsa decemlineata and Colaphellus bowringi). Biotechnol. Lett. 2009, 31, 697-703. [CrossRef] [PubMed]

117. Gao, Y.; Jurat-Fuentes, J.L.; Oppert, B.; Fabrick, J.A.; Liu, C.; Gao, J.; Lei, Z. Increased toxicity of Bacillus thuringiensis Cry3Aa against Crioceris quatuordecimpunctata, Phaedon brassicae and Colaphellus bowringi by a Tenebrio molitor cadherin fragment. Pest Manag. Sci. 2011,67, 1076-1081. [CrossRef]

118. Park, Y.; Abdullah, M.A.F.; Taylor, M.D.; Rahman, K.; Adang, M.J. Enhancement of Bacillus thuringiensis Cry3Aa and Cry3Bb Toxicities to Coleopteran Larvae by a Toxin-Binding Fragment of an Insect Cadherin. Appl. Environ. Microbiol. 2009, 75, 3086-3092. [CrossRef] [PubMed]

119. Li, H.; Olson, M.; Lin, G.; Hey, T.; Tan, S.Y.; Narva, K.E. Bacillus thuringiensis Cry34Ab1/Cry35Ab1 interactions with Western Corn Rootworm Midgut Membrane Binding Sites. PLoS ONE 2013, 8, e53079. [CrossRef] [PubMed]

120. Carroll, J.S.; Li, J.; Ellar, D.J. Proteolytic processing of a coleopteran-specific delta-endotoxin produced by Bacillus thuringiensis var. tenebrionis. Biochem. J. 1989, 261, 99-105. [CrossRef] [PubMed]

121. Wang, G.; Zhang, J.; Song, F.; Wu, J.; Feng, S.; Huang, D. Engineered Bacillus thuringiensis GO33A with broad insecticidal activity against lepidopteran and coleopteran pests. Appl. Microbiol. Biotechnol. 2006, 72, 924-930. [CrossRef] [PubMed]

122. Mahadeva Swamy, H.M.; Asokan, R.; Thimmegowda, G.G.; Mahmood, R. Expression of cry3A gene and its toxicity against Asian Gray Weevil Myllocerus undecimpustulatus undatus Marshall (Coleoptera: Curculionidae). J. Basic Microbiol. 2013, 53, 664-676. [CrossRef]

123. Gomez, S.; Mateus, A.C.; Hernandez, J.; Zimmermann, B.H. Recombinant Cry3Aa has insecticidal activity against the Andean potato weevil, Premnotrypes vorax. Biochem. Biophys. Res. Commun. 2000, 279, 653-656. [CrossRef]

124. Johnson, T.M.; Rishi, A.S.; Nayak, P.; Sen, S.K. Cloning of a cryIIIA endotoxin gene of Bacillus thuringiensis var. tenebrionis and its transient expression inindica rice. J. Biosci. 1996, 21, 673-685.

125. Adang, M.J. Enhancement of Bacillus thuringiensis Cry Toxicities to Lesser Mealworm Alphitobius diaperinus. U.S. Patent 0,201,549 A1, 18 August 2011.

126. Wu, S.-J.; Dean, D.H. Functional Significance of Loops in The Receptor Binding Domain of Bacillus thuringiensis CryIIIA $\delta$-Endotoxin. J. Mol. Biol. 1996, 255, 628-640. [CrossRef] [PubMed]

127. Fabrick, J.; Oppert, C.; Lorenzen, M.D.; Morris, K.; Oppert, B.; Jurat-Fuentes, J.L. A Novel Tenebrio molitor Cadherin Is a functional receptor for Bacillus thuringiensis Cry3Aa toxin. J. Biol. Chem. 2009, 284, 18401-18410. [CrossRef]

128. Donovan, W.P.; Rupar, M.J.; Slaney, A.C.; Malvar, T.; Gawron-Burke, M.C.; Johnson, T.B. Characterization of two genes encoding Bacillus thuringiensis insecticidal crystal proteins toxic to Coleoptera species. Appl. Environ. Microbiol. 1992, 58, 3921-3927. [CrossRef]

129. Adang, M.J.; Adang, M.J.; Abdullah, M.A.F. Enhancement of Bacilus thuringiensis Cry Protein Toxicities to Coleopterans, and Novel Insect Cadhetin Fragments. U.S. Patent 8,486,887 B2, 16 July 2013.

130. Lambert, B.; Theunis, W.; Aguda, R.; Van Audenhove, K.; Decock, C.; Jansens, S.; Seurinck, J.; Peferoen, M. Nucleotide sequence of gene crylllD encoding a novel coleopteran-active crystal protein from strain BTII09P of Bacillus thuringiensis subsp. Kurstaki Gene 1992, 110, 131-132. [CrossRef]

131. Haffani, Y.Z.; Cloutier, C.; Belzile, F.J. Bacillus thuringiensis cry3Ca1 protein is toxic to the Colorado Potato Beetle, Leptinotarsa decemlineata (Say). Biotechnol. Prog. 2001, 17, 211-216. [CrossRef] [PubMed] 
132. Deng, S.; Shu, C.; Lin, Y.; Song, F.; Zhang, J. Identification, cloning and expression for novel cry7Ab gene and its insecticidal activity. J. Agric. Biotechnol. 2009, 17, 908-913.

133. Wang, L.; Guo, W.; Tan, J.; Sun, W.; Liu, T.; Sun, Y. Construction of an engineering strain expressing $c r y 7 A b 7$ gene cloned from Bacillus thuringiensis. Front. Agric. China 2010, 4, 328-333. [CrossRef]

134. Foncerrada, L.; Sick, A.J.; Payne, J.M. Novel Coleopteran-Active Bacillus thuringiensis Isolate and a Novel Gene Encoding a Coleopteran-Active Toxin. Patent Application EP0498537 A2, 16 January 1992. pp. 1-5.

135. Michaels, T.E.; Narva, K.E.; Foncerrada, L. Bacillus thuringiensis Toxins Active against Scarab Pests. U.S. Patent 5,554,534 A, 10 September 1996.

136. Zhang, Y.; Zheng, G.; Tan, J.; Li, C.; Cheng, L. Cloning and characterization of a novel cry $8 A b 1$ gene from Bacillus thuringiensis strain B-JJX with specific toxicity to scarabaeid (Coleoptera: Scarabaeidae) larvae. Microbiol. Res. 2013, 168, 512-517. [CrossRef]

137. Michaels, T.E.; Foncerrada, L.; Narva, K.E. Process for Controlling Scarab Pests with Bacillus thuringiensis Isolates. International Patent Application WO 93/15206, 5 August 1993.

138. Abad, A.; Duck, N.B.; Feng, X.; Flannagan, R.D.; Kahn, T.W.; Sims, L.E. Genes encoding Novel Proteins with Pesticidal Activity against Coleopterans. International Patent Application WO 02/034774 A2, 2 May 2002.

139. Liu, J.; Yan, G.; Shu, C.; Zhao, C.; Liu, C.; Song, F.; Zhou, L.; Ma, J.; Zhang, J.; Huang, D. Construction of a Bacillus thuringiensis engineered strain with high toxicity and broad pesticidal spectrum against coleopteran insects. Appl. Microbiol. Biotechnol. 2010, 87, 243-249. [CrossRef]

140. Jia, Y.; Zhao, C.; Wang, Q.; Shu, C.; Feng, X.; Song, F.; Zhang, J. A genetically modified broad-spectrum strain of Bacillus thuringiensis toxic against Holotrichia parallela, Anomala corpulenta and Holotrichia oblita. World J. Microbiol. Biotechnol. 2014, 30, 595-603. [CrossRef] [PubMed]

141. Sato, R.; Takeuchi, K.; Ogiwara, K.; Minami, M.; Kaji, Y.; Suzuki, N.; Hori, H.; Asano, S.; Ohba, M.; Iwahana, H. Cloning, heterologous expression, and localization of a novel crystal protein gene from Bacillus thuringiensis serovar japonensis strain Buibui toxic to scarabaeid insects. Curr. Microbiol. 1994, 28, 15-19. [CrossRef] [PubMed]

142. Huang, D.-F.; Zhang, J.; Song, F.-P.; Lang, Z.-H. Microbial control and biotechnology research on Bacillus thuringiensis in China. J. Invertebr. Pathol. 2007, 95, 175-180. [CrossRef] [PubMed]

143. Asano, S.; Yamashita, C.; Iizuka, T.; Takeuchi, K.; Yamanaka, S.; Cerf, D.; Yamamoto, T. A strain of Bacillus thuringiensis subsp. galleriae containing a novel cry8 gene highly toxic to Anomala cuprea (Coleoptera: Scarabaeidae). Biol. Control 2003, 28, 191-196. [CrossRef]

144. Liu, X.; Cheng, L.; Li, T.; Li, C.; Li, G. Cloning, expression and insecticidal activity of cry8Ea2 gene from Bacillus thuringiensis strain B. Acta Agric. Boreali-Sin. 2008, 23, 1-4.

145. Singaravelu, B.; Crickmore, N.; Srikanth, J.; Hari, K.; Sankaranarayanan, C. Prospecting for Scarabid Specific Bacillus thuringiensis Crystal toxin cry8 gene in sugarcane ecosystem of Tamil Nadu, India. J. Sugarcane Res. 2013, 3, 141-144.

146. Silva-Werneck, J.O.; Ellar, D.J. Characterization of a novel Cry9Bb $\delta$-endotoxin from Bacillus thuringiensis. J. Invertebr. Pathol. 2008, 98, 320-328. [CrossRef]

147. Brown, K.L.; Whiteley, H.R. Molecular characterization of two novel crystal protein genes from Bacillus thuringiensis subsp. thompsoni. J. Bacteriol. 1992, 174, 549-557. [CrossRef]

148. Zhang, J.; Hodgman, T.C.; Krieger, L.; Schnetter, W.; Schairer, H.U. Cloning and analysis of the first cry gene from Bacillus popilliae. J. Bacteriol. 1997, 179, 4336-4341. [CrossRef]

149. Guzov, V.M.; Malvar, T.M.; Roberts, J.K.; Sivasupramanian, S. Insect Inhibitory Bacillus thuringiensis Proteins, Fusions, and Methods of Use Therefor. U.S. Patent 7,655,838 B2, 2 February 2010.

150. Herman, R.A.; Scherer, P.N.; Young, D.L.; Mihaliak, C.A.; Woodsworth, A.T.; Stockhoff, B.A.; Narva, K.E. Binary Insecticidal Crystal Protein from Bacillus thuringiensis, Strain PS149B1: Effects of Individual Protein Components and Mixtures in Laboratory Bioassays. J. Econ. Entomol. 2002, 95, 635-639. [CrossRef]

151. Rupar, M.J.; Donovan, W.P.; Chu, C.R.; Pease, E.; Tan, Y.; Slaney, A.C.; Malvar, T.M.; Baum, J. Coleopteran Toxin Polypeptide Compositions and Insect-Resistant Transgenic Plants. U.S. Patent 090,094,714 A1, 9 April 2009.

152. Yokoyama, T.; Tanaka, M.; Hasegawa, M. Novel cry gene from Paenibacillus lentimorbus strain Semadara inhibits ingestion and promotes insecticidal activity in Anomala cuprea larvae. J. Invertebr. Pathol. 2004, 85, 25-32. [CrossRef] [PubMed] 
153. de Maagd, R.A.; Kwa, M.S.; van der Klei, H.; Yamamoto, T.; Schipper, B.; Vlak, J.M.; Stiekema, W.J.; Bosch, D. Domain III substitution in Bacillus thuringiensis delta-endotoxin CryIA(b) results in superior toxicity for Spodoptera exigua and altered membrane protein recognition. Appl. Environ. Microbiol. 1996, 62, 1537-1543. [CrossRef] [PubMed]

154. Shadenkov, A.A.; Kadyrov, R.M.; Uzbekova, S.V.; Kuz'min, E.V.; Osterman, A.L.; Chestukhina, G.G.; Shemiakin, M.F. Creation of a hybrid protein gene based on Bacillus thuringiensis delta endotoxins CryIIIA and CrIA(a) and expression of its derivatives in Escherichia coli. Mol. Biol. 1993, 27, 952-959.

155. Walters, F.S.; DeFontes, C.M.; Hart, H.; Warren, G.W.; Chen, J.S. Lepidopteran-Active Variable-Region Sequence Imparts Coleopteran Activity in eCry3.1Ab, an Engineered Bacillus thuringiensis Hybrid Insecticidal Protein. Appl. Environ. Microbiol. 2010, 76, 3082-3088. [CrossRef] [PubMed]

156. English, L.; Brussock, M.; Malvar, T.M.; Bryson, J.; Kulesza, C.; Walters, F.S.; Slatin, S.; von Tersch, M.A.; Romano, C. Nucleic Acid Segments Encoding Modified Bacillus thuringiensis Coleopteran-Toxic Crystal Proteins. U.S. Patent 6,060,594, 9 May 2000.

157. Walters, F.S.; Stacy, C.M.; Lee, M.K.; Palekar, N.; Chen, J.S. An engineered Chymotrypsin/Cathepsin $\mathrm{G}$ site in Domain I renders Bacillus thuringiensis Cry3A active against Western Corn Rootworm larvae. Appl. Environ. Microbiol. 2008, 74, 367-374. [CrossRef]

158. Jouzani, G.S.; Valijanian, E.; Sharafi, R. Bacillus thuringiensis: A successful insecticide with new environmental features and tidings. Appl. Microbiol. Biotechnol. 2017, 101, 2691-2711. [CrossRef]

159. Jurat-Fuentes, J.L.; Crickmore, N. Specificity determinants for Cry insecticidal proteins: Insights from their mode of action. J. Invertebr. Pathol. 2017, 142, 5-10. [CrossRef]

160. Guo, S.; Li, J.; Liu, Y.; Song, F.; Zhang, J. The role of DNA binding with the Cry8Ea1 toxin of Bacillus thuringiensis. FEMS Microbiol. Lett. 2011, 317, 203-210. [CrossRef]

161. Xia, L.; Sun, Y.; Ding, X.; Fu, Z.; Mo, X.; Zhang, H.; Yuan, Z. Identification of cry-Type Genes on 20-kb DNA Associated with Cry1 Crystal Proteins from Bacillus thuringiensis. Curr. Microbiol. 2005, 51, 53-58. [CrossRef]

162. Wu, F.; Zhao, X.; Sun, Y.; Li, W.; Xia, L.; Ding, X.; Yin, J.; Hu, S.; Yu, Z.; Tang, Y. Construction of gene library of $20 \mathrm{~kb}$ DNAs from parasporal Crystal in Bacillus thuringiensis strain 4.0718: Phylogenetic analysis and molecular docking. Curr. Microbiol. 2012, 64, 106-111. [CrossRef]

163. Ai, B.; Li, J.; Feng, D.; Li, F.; Guo, S. The Elimination of DNA from the Cry Toxin-DNA Complex Is a Necessary Step in the Mode of Action of the Cry8 Toxin. PLoS ONE 2013, 8, e81335. [CrossRef] [PubMed]

164. Koller, C.N.; Bauer, L.S.; Hollingworth, R.M. Characterization of the pH-mediated solubility of Bacillus thuringiensis var. san diego native $\delta$-endotoxin crystals. Biochem. Biophys. Res. Commun. 1992, 184, 692-699. [CrossRef]

165. Chougule, N.P.; Doyle, E.; Fitches, E.; Gatehouse, J.A. Biochemical characterization of midgut digestive proteases from Mamestra brassicae (cabbage moth; Lepidoptera: Noctuidae) and effect of soybean Kunitz inhibitor (SKTI) in feeding assays. J. Insect Physiol. 2008, 54, 563-572. [CrossRef] [PubMed]

166. Michaud, D.; Bernier-Vadnais, N.; Overney, S.; Yelle, S. Constitutive expression of digestive cysteine proteinase forms during development of the colorado potato beetle, Leptinotarsa decemlineata Say (Coleoptera: Chrysomelidae). Insect Biochem. Mol. Biol. 1995, 25, 1041-1048. [CrossRef]

167. Yamaguchi, T.; Sahara, K.; Bando, H.; Asano, S. Intramolecular proteolytic nicking and binding of Bacillus thuringiensis Cry8Da toxin in BBMVs of Japanese beetle. J. Invertebr. Pathol. 2010, 105, 243-247. [CrossRef]

168. Rausell, C.; García-Robles, I.; Sánchez, J.; Muñoz-Garay, C.; Martínez-Ramírez, A.C.; Real, M.D.; Bravo, A. Role of toxin activation on binding and pore formation activity of the Bacillus thuringiensis Cry3 toxins in membranes of Leptinotarsa decemlineata (Say). Biochim. Biophys. Acta Biomembr. 2004, 1660, 99-105. [CrossRef]

169. Hernández-Martínez, P.; Vera-Velasco, N.M.; Martínez-Solís, M.; Ghislain, M.; Ferré, J.; Escriche, B. Shared binding sites for the Bacillus thuringiensis proteins Cry3Bb, Cry3Ca, and Cry7Aa in the African Sweet Potato Pest Cylas puncticollis (Brentidae). Appl. Environ. Microbiol. 2014, 80, 7545-7550. [CrossRef]

170. Ochoa-Campuzano, C.; Real, M.D.; Martínez-Ramírez, A.C.; Bravo, A.; Rausell, C. An ADAM metalloprotease is a Cry3Aa Bacillus thuringiensis toxin receptor. Biochem. Biophys. Res. Commun. 2007,362, 437-442. [CrossRef]

171. Zúñiga-Navarrete, F.; Gómez, I.; Peña, G.; Bravo, A.; Soberón, M. A Tenebrio molitor GPI-anchored alkaline phosphatase is involved in binding of Bacillus thuringiensis Cry3Aa to brush border membrane vesicles. Peptides 2013, 41, 81-86. [CrossRef] 
172. Siegfried, B.D.; Waterfield, N.; Ffrench-Constant, R.H. Expressed sequence tags from Diabrotica virgifera virgifera midgut identify a coleopteran cadherin and a diversity of cathepsins. Insect Mol. Biol. 2005, 14, 137-143. [CrossRef]

173. Sayed, A.; Nekl, E.R.; Siqueira, H.A.A.; Wang, H.-C.; Ffrench-Constant, R.H.; Bagley, M.; Siegfried, B.D. A novel cadherin-like gene from western corn rootworm, Diabrotica virgifera virgifera (Coleoptera: Chrysomelidae), larval midgut tissue. Insect Mol. Biol. 2007, 16. [CrossRef] [PubMed]

174. Contreras, E.; Schoppmeier, M.; Real, M.D.; Rausell, C. Sodium Solute Symporter and Cadherin proteins Act as Bacillus thuringiensis Cry3Ba toxin functional receptors in Tribolium castaneum. J. Biol. Chem. 2013, 288, 18013-18021. [CrossRef] [PubMed]

175. Shu, C.; Tan, S.; Yin, J.; Soberón, M.; Bravo, A.; Liu, C.; Geng, L.; Song, F.; Li, K.; Zhang, J. Assembling of Holotrichia parallela (dark black chafer) midgut tissue transcriptome and identification of midgut proteins that bind to Cry8Ea toxin from Bacillus thuringiensis. Appl. Microbiol. Biotechnol. 2015, 99, 7209-7218. [CrossRef] [PubMed]

176. Jiang, J.; Huang, Y.; Shu, C.; Soberón, M.; Bravo, A.; Liu, C.; Song, F.; Lai, J.; Zhang, J. Holotrichia oblita Midgut Proteins That Bind to Bacillus thuringiensis Cry8-Like Toxin and Assembly of the H. oblita Midgut Tissue Transcriptome. Appl. Environ. Microbiol. 2017, 83, 1-11. [CrossRef]

177. Yamaguchi, T.; Bando, H.; Asano, S. Identification of a Bacillus thuringiensis Cry8Da toxin-binding glucosidase from the adult Japanese beetle, Popillia japonica. J. Invertebr. Pathol. 2013, 113, 123-128. [CrossRef]

178. Pérez, C.; Muñoz-Garay, C.; Portugal, L.C.; Sánchez, J.; Gill, S.S.; Soberón, M.; Bravo, A. Bacillus thuringiensis ssp. israelensis Cyt1Aa enhances activity of Cry11Aa toxin by facilitating the formation of a pre-pore oligomeric structure. Cell. Microbiol. 2007, 9, 2931-2937.

179. Khorramnejad, A.; Domínguez-Arrizabalaga, M.; Caballero, P.; Escriche, B.; Bel, Y. Study of the Bacillus thuringiensis Cry1Ia protein oligomerization promoted by midgut Brush Border Membrane Vesicles of lepidopteran and coleopteran insects, or cultured insect cells. Toxins 2020, 12, 133. [CrossRef]

180. Warren, G.W.; Koziel, M.G.; Mullins, M.A.; Kostichka, K.; Estruch, J.J. Novel Pesticidal Proteins and Strains. Patent Coop. Treaty WO 96/10083 A1, 4 April 1996.

181. Donovan, W.P.; Engleman, J.T.; Donovan, J.C.; Baum, J.A.; Bunkers, G.J.; Chi, D.J.; Clinton, W.P.; English, L.; Heck, G.R.; Ilagan, O.M.; et al. Discovery and characterization of Sip1A: A novel secreted protein from Bacillus thuringiensis with activity against coleopteran larvae. Appl. Microbiol. Biotechnol. 2006, 72, 713-719. [CrossRef]

182. Sattar, S.; Maiti, M.K. Molecular Characterization of a Novel Vegetative Insecticidal Protein from Bacillus thuringiensis Effective Against Sap-Sucking Insect Pest. J. Microbiol. Biotechnol. 2011, 21, 937-946. [CrossRef]

183. Estruch, J.J.; Warren, G.W.; Mullins, M.A.; Nye, G.J.; Craig, J.A.; Koziel, M.G. Vip3A, a novel Bacillus thuringiensis vegetative insecticidal protein with a wide spectrum of activities against lepidopteran insects. Proc. Natl. Acad. Sci. USA 1996, 93, 5389-5394. [CrossRef]

184. Sha, J.; Zhang, J.; Chi, B.; Liu, R.; Li, H.; Gao, J. sip1Ab gene from a native Bacillus thuringiensis strain QZL38 and its insecticidal activity against Colaphellus bowringi Baly. Biocontrol Sci. Technol. 2018, 28, $459-467$. [CrossRef]

185. Warren, G.W. Vegetative Insecticidal Proteins. In Advances in Insect Control; Taylor \& Francis: Abingdon, UK, 1997; pp. 109-122.

186. Han, S.; Craig, J.A.; Putnam, C.D.; Carozzi, N.B.; Tainer, J.A. Evolution and mechanism from structures of an ADP-ribosylating toxin and NAD complex. Nat. Struct. Biol. 1999, 6, 932-936.

187. Shi, Y.; Ma, W.; Yuan, M.; Sun, F.; Pang, Y. Cloning of vip1/vip2 genes and expression of Vip1Ca/Vip2Ac proteins in Bacillus thuringiensis. World J. Microbiol. Biotechnol. 2007, 23, 501-507. [CrossRef]

188. Barth, H.; Aktories, K.; Popoff, M.R.; Stiles, B.G. Binary bacterial toxins: Biochemistry, biology, and applications of common Clostridium and Bacillus proteins. Microbiol. Mol. Biol. Rev. 2004, 68, 373-402. [CrossRef] [PubMed]

189. Chakroun, M.; Banyuls, N.; Bel, Y.; Escriche, B.; Ferré, J. Bacterial Vegetative Insecticidal Proteins (Vip) from Entomopathogenic Bacteria. Microbiol. Mol. Biol. Rev. 2016, 80, 329-350. [CrossRef]

190. Feitelson, J.S.; Schnepf, H.E.; Narva, K.E.; Stockhoff, B.A.; Schmeits, J.; Loewer, D.; Dullum, C.J.; Muller-Cohn, J.; Stamp, L. Pesticidal Toxins and Nucleotide Sequences Which Encode These Toxins. U.S. Patent 6,204,435 B1, 20 March 2001.

191. Boets, A.; Arnaut, G.; Van Rie, J.; Damme, N. Toxins. U.S. Patent 7,919,609 B2, 5 April 2011. 
192. Bi, Y.; Zhang, Y.; Shu, C.; Crickmore, N.; Wang, Q.; Du, L.; Song, F.; Zhang, J. Genomic sequencing identifies novel Bacillus thuringiensis Vip1/Vip2 binary and Cry8 toxins that have high toxicity to Scarabaeoidea larvae. Appl. Microbiol. Biotechnol. 2015, 99, 753-760. [CrossRef]

193. Leuber, M.; Orlik, F.; Schiffler, B.; Sickmann, A.; Benz, R. Vegetative Insecticidal Protein (Vip1Ac) of Bacillus thuringiensis HD201: Evidence for oligomer and channel formation. Biochemistry 2006, 45, 283-288. [CrossRef]

194. Geng, J.; Jiang, J.; Shu, C.; Wang, Z.; Song, F.; Geng, L.; Duan, J.; Zhang, J. Bacillus thuringiensis Vip1 functions as a receptor of Vip2 toxin for binary insecticidal activity against Holotrichia parallela. Toxins 2019, 11, 440. [CrossRef]

195. Shi, Y.; Xu, W.; Yuan, M.; Tang, M.; Chen, J.; Pang, Y. Expression of vip1/vip2 genes in Escherichia coli and Bacillus thuringiensis and the analysis of their signal peptides. J. Appl. Microbiol. 2004, 97, 757-765. [CrossRef]

196. Yu, X.; Liu, T.; Liang, X.; Tang, C.; Zhu, J.; Wang, S.; Li, S.; Deng, Q.; Wang, L.; Zheng, A.; et al. Rapid detection of vip1-type genes from Bacillus cereus and characterization of a novel vip binary toxin gene. FEMS Microbiol. Lett. 2011, 325, 30-36. [CrossRef]

197. Baranek, J.; Kaznowski, A.; Konecka, E.; Naimov, S. Activity of vegetative insecticidal proteins Vip3Aa58 and Vip3Aa59 of Bacillus thuringiensis against lepidopteran pests. J. Invertebr. Pathol. 2015, 130, 72-81. [CrossRef] [PubMed]

198. Wraight, S.P.; Lacey, L.A.; Kabaluk, J.T.; Gottel, M.S. Potential for Microbial Biological Control of Coleopteran and Hemipteran Pests of Potato-Agriculture and Agri-Food Canada (AAFC). Fruit Veg. Cereal Sci. Biotechnol. 2009, 3, 25-38.

199. Beveridge, N.; Elek, J.A. Insect and host-tree species influence the effectiveness of a Bacillus thuringiensis ssp. tenebrionis-based insecticide for controlling chrysomelid leaf beetles. Aust. J. Entomol. 2001, 40, 386-390. [CrossRef]

200. Coyle, D.R.; McMillin, J.D.; Krause, S.C.; Hart, E.R. Laboratory and field evaluations of two Bacillus thuringiensis formulations, Novodor and Raven, for control of Cottonwood Leaf Beetle (Coleoptera: Chrysomelidae). J. Econ. Entomol. 2000, 93, 713-720. [CrossRef] [PubMed]

201. Way, M.O.; Wallace, R.G.; Harper, H.B.; Landry, C.L. Control of Rice Water Weevil with Novodor 3, 1999. Arthropod Manag. Tests 2000, 25, 133. [CrossRef]

202. Baum, J.A.; Johnson, T.B. Bacillus thuringiensis: Natural and recombinant bioinsecticide products. In Methods in Biotechnology, Vol5: Biopesticides: Use and Deliver; Humana Press Inc.: Totowa, NJ, USA, 1999; pp. 189-209.

203. Sanchis, V. From microbial sprays to insect-resistant transgenic plants: History of the biospesticide Bacillus thuringiensis. A review. Agron. Sustain. Dev. 2011, 31, 217-231. [CrossRef]

204. Gawron-Burke, C.; Baum, J.A. Genetic Manipulation of Bacillus thuringiensis Insecticidal Crystal Protein Genes in Bacteria. In Genetic Engineering; Springer US: Boston, MA, USA, 1991; Volume 13, pp. 237-263.

205. Baum, J.A.; Kakefuda, M.; Gawron-burke, C. Engineering Bacillus thuringiensis Bioinsecticides with an Indigenous Site-Specific Recombination System. Appl. Environ. Microbiol. 1996, 62, 4367-4373. [CrossRef]

206. Perlak, F.; Stone, T.; Muskopf, Y.; Petersen, L.; Parker, G.; McPherson, S.; Wyman, J.; Love, S.; Reed, G.; Biever, D. Genetically improved potatoes: Protection from damage by Colorado potato beetles. Plant Mol. Biol. 1993, 22, 313-321. [CrossRef]

207. Duncan, D.R.; Hammond, D.; Zalewski, J.; Cudnohufsky, J.; Kaniewski, W.; Thornton, M.; Bookout, J.T.; Lavrik, P.; Rogan, G.J.; Feldman-Riebe, J. Field performance of “Transgenic" potato, with resistance to Colorado Potato Beetle and Viruses. HortScience 2002, 37, 556E-557. [CrossRef]

208. Thomas, P.E.; Kaniewski, W.K.; Lawson, E.C. Reduced Field Spread of Potato Leafroll Virus in Potatoes Transformed with the Potato Leafroll Virus Coat Protein Gene. Plant Dis. 1997, 81, 1447-1453. [CrossRef]

209. Thornton, M. The Rise and Fall of NewLeaf Potatoes. NABC Rep. 2004, 15, 235-243.

210. Vaughn, T.; Cavato, T.; Brar, G.; Coombe, T.; DeGooyer, T.; Ford, S.; Groth, M.; Howe, A.; Johnson, S.; Kolacz, K.; et al. A Method of controlling corn rootworm feeding using a Bacillus thuringiensis protein expressed in transgenic maize. Crop Sci. 2005, 45, 931-938. [CrossRef]

211. Gassmann, A.J.; Shrestha, R.B.; Jakka, S.R.K.; Dunbar, M.W.; Clifton, E.H.; Paolino, A.R.; Ingber, D.A.; French, B.W.; Masloski, K.E.; Dounda, J.W.; et al. Evidence of resistance to Cry34/35Ab1 Corn by Western corn rootworm (Coleoptera: Chrysomelidae): Root Injury in the Field and Larval Survival in Plant-Based Bioassays. J. Econ. Entomol. 2016, 109, 1872-1880. [CrossRef] 
212. Zukoff, S.N.; Ostlie, K.R.; Potter, B.; Meihls, L.N.; Zukoff, A.L.; French, L.; Ellersieck, M.R.; French, B.W.; Hibbard, B.E. Multiple assays indicate varying levels of cross resistance in Cry3Bb1-selected field populations of the western corn rootworm to mCry3A, eCry3.1Ab, and Cry34/35Ab1. J. Econ. Entomol. 2016, 109, 1387-1398. [CrossRef] [PubMed]

213. Wangila, D.S.; Gassmann, A.J.; Petzold-Maxwell, J.L.; French, B.W.; Meinke, L.J. Susceptibility of Nebraska Western Corn Rootworm (Coleoptera: Chrysomelidae) populations to Bt corn events. J. Econ. Entomol. 2015, 108, 742-751. [CrossRef]

214. Jakka, S.R.K.; Shrestha, R.B.; Gassmann, A.J. Broad-spectrum resistance to Bacillus thuringiensis toxins by western corn rootworm (Diabrotica virgifera virgifera). Sci. Rep. 2016, 6, 27860. [CrossRef]

215. Shrestha, R.B.; Dunbar, M.W.; French, B.W.; Gassmann, A.J. Effects of field history on resistance to Bt maize by western corn rootworm, Diabrotica virgifera virgifera LeConte. PLoS ONE 2018, 13, e0200156. [CrossRef]

216. Ferré, J.; Van Rie, J.; Macintosh, S.C. Insecticidal Genetically Modified Crops and Insect Resistance Management (IRM). In Integration of Insect-Resistant Genetically Modified Cropts within IPM Programs; Springer Science + Business Media: Dordrecht, The Netherlands, 2008.

217. Carrière, Y.; Crickmore, N.; Tabashnik, B.E. Optimizing yramided transgenic Bt crops for sustainable pest management. Nat. Biotechnol. 2015, 33, 61-168. [CrossRef] [PubMed]

218. Onstad, D.W.; Meinke, L.J. Modeling evolution of Diabrotica virgifera virgifera to transgenic corn with two insecticidal traits. J. Econ. Entomol. 2010, 103, 849-860. [CrossRef] [PubMed]

(C) 2020 by the authors. Licensee MDPI, Basel, Switzerland. This article is an open access article distributed under the terms and conditions of the Creative Commons Attribution (CC BY) license (http://creativecommons.org/licenses/by/4.0/). 